\title{
Evaluation of forward osmosis membrane performance and fouling during long-term osmotic membrane bioreactor study
}

\author{
Elizabeth A. Bell ${ }^{1}$, Ryan W. Holloway ${ }^{1,2}$, and Tzahi Y. Cath ${ }^{1 *}$ \\ ${ }^{1}$ Colorado School of Mines, Golden, CO, USA \\ ${ }^{2}$ Kennedy/Jenks Consultants, San Francisco, CA, USA
}

* Corresponding author: e-mail: tcath@mines.edu; phone: (303) 273-3402; fax: (303) 273-3413

A manuscript prepared for possible publication in the

Journal of Membrane Science

December 2016 


\begin{abstract}
Forward osmosis membrane performance and fouling was studied during 100 days of continuous activated sludge treatment. The purpose of the study was to compare the performance and fouling of commercial cellulose triacetate and newly developed polyamide thin film composite membranes that treated high salinity and low salinity activated sludge from two membrane bioreactors. Water flux, reverse salt flux, and specific reverse salt flux were measured to evaluate the performance of virgin and fouled membranes. Membrane autopsy was used to investigate foulant composition and compare physicochemical membrane properties before and after fouling. The results indicated that both membrane types attained steady-state water flux over 100 days, characterized by an initial decline and subsequent steady-state period. Biofouling and organic fouling caused overall water flux decline, in which foulants were identical between membrane and activated sludge types. Water flux results were similar for the two activated sludge types and demonstrated that FO membrane performance and fouling was independent of total dissolved solids, calcium, and mixed liquor suspended solid concentrations. Lastly, virgin membrane properties (i.e., hydrophilicity and surface roughness) did not contribute substantially to membrane fouling. Cellulose triacetate membranes outperformed thin film composite membranes, with lower fouling propensity, higher water flux, lower reverse salt flux, and lower specific reverse salt flux.
\end{abstract}

Keywords: forward osmosis; osmotic membrane bioreactor; membrane fouling; wastewater treatment; water reuse 


\section{Introduction}

The osmotic membrane bioreactor (OMBR) is a novel advanced wastewater treatment system that uses highly selective forward osmosis (FO) membranes to allow water permeation from activated sludge feed solutions to saline draw solutions (DS) [1-5]. The process is driven by the osmotic pressure difference across an FO membrane, between a low-salinity activated sludge feed stream and high-salinity DS. The nonporous FO membranes used in OMBRs reliably reject pathogens [6], trace organic compounds [5, 7-14], and ions [15, 16], making the OMBR an attractive technology for water reuse. However, one of the main challenges associated with the operation of OMBR and conventional membrane separation processes is membrane fouling, which shortens the membrane life $[17,18]$, decreases water production $[18,19]$, and increases operating costs [19].

FO is commonly described as having a low fouling propensity compared to pressure driven membrane technologies such as reverse osmosis (RO) and nanofiltration (NF) [20-22]. Although FO membranes have a lower fouling propensity, FO membrane fouling still occurs and periodic membrane cleaning is required [1, 3]. Furthermore, OMBR membrane cleaning is more difficult than cleaning microfiltration (MF) and ultrafiltration (UF) membranes used in membrane bioreactors (MBRs), which are commonly cleaned using hydraulic and chemical backwashing [18]. OMBR membranes can be cleaned using osmotic backwashing, in which the concentrated DS is flushed from the DS side of the membrane and replaced with a very low-salinity cleaning solution (e.g., deionized water or de-chlorinated municipal water). The low-salinity cleaning solution diffuses from the DS through the membrane to the feed; thereby, attached organic and inorganic particles are dislodged and dissolved from the membrane surface. Due to the complexity and time intensive nature of osmotic backwashing, it is important to mitigate FO membrane fouling to minimize the frequency of FO membrane cleaning in OMBR operations.

In general, membrane fouling is grouped into three categories: biofouling, organic fouling, and inorganic fouling (i.e., scaling) [23]. Biofouling is the result of biofilm formation through a series of fundamental steps, including reversible attachment of planktonic bacteria, irreversible attachment of more bacterial cells (e.g., through bacterial quorum-sensing), cell growth and extracellular polymeric substance (EPS) production, and ultimately the formation of a mature biofilm [24, 25]. Organic fouling is the adsorption of organic compounds (e.g., EPS, soluble microbial products (SMPs), and humic substances) from the feed stream onto the membrane 
surface [18, 23, 25], and inorganic fouling is the chemical or biological precipitation of inorganic solids (e.g., struvite [26], $\mathrm{CaCO}_{3}$ [27], and $\mathrm{CaSO}_{4}$ [28]) onto the membrane surface.

The extent of membrane fouling due to biofouling, organic fouling, and inorganic fouling depends on a number of factors, including physicochemical membrane properties and wastewater composition [25, 29]. Hydrophilic membranes with relatively low roughness and neutral charge are generally considered to be the most resistant to fouling [25, 30-32]. Although these physicochemical properties have been used to explain differences in membrane fouling propensity, the effect of physicochemical membrane properties on fouling is uncertain. For example, Wang et al. [33] and Maximous et al. [34] concluded that hydrophilicity only deters initial colloidal fouling (e.g., bacterial attachment) and enhances membrane cleaning efficacy, while long-term fouling is dominated by foulant-foulant interactions. In terms of surface morphology, several studies have shown that smoother membranes may facilitate more effective membrane cleaning but no clear correlation between fouling and membrane roughness could be established [34, 35]. Most studies still propose that hydrophilic and smooth membranes should be used to minimize fouling, but these studies also suggest that further work is needed to understand membrane properties and their effects on long-term fouling [36-39].

The composition of the wastewater is also critical to FO membrane fouling [25]. The organic and inorganic composition of the activated sludge in OMBRs is very different compared to more traditional activated sludge processes because the OMBR is often operated at high solids retention times (SRT) and elevated salt concentrations. The salt concentration of the activated sludge is higher in OMBRs because salts contained in the influent are retained in the bioreactors by the FO membranes and salts diffuse across the FO membrane from the DS to the feed. Salt accumulation in the OMBR has been shown to inhibit microbial activity [1, 40, 41], reduce the osmotic driving force for water flux (difference in salt concentration between the feed and DS) $[1,42]$ and lead to higher divalent ion concentrations in the bioreactors (e.g., $\mathrm{Ca}^{2+}$ and $\mathrm{Mg}^{2+}$ ) [1, 36, 43, 44]. Divalent ions are considered major contributors to fouling due to bridging between the divalent ions and organic matter, resulting in more severe membrane fouling [20, 36, 37]. Salt accumulation also increases the ionic strength of the wastewater, which may increase bacterial adhesion to the membrane [45] and change the membrane surface charge (zeta potential) [46]. Coday et al. [46] demonstrated that increasing ionic strength reduced the negative 
charge of FO membranes, which can potentially affect membrane fouling propensity and the bidirectional diffusion of ionic constituents across the membrane [46-48].

The majority of studies exploring FO membrane fouling mechanisms have used synthetic feed solutions [3, 20, 22, 29, 36-38, 49-58]; however, relatively few studies have examined OMBR membrane fouling using real wastewaters [1, 2, 43, 59, 60]. This is a major shortcoming in the literature because the use of synthetic or real wastewater can substantially influence the extent and characteristics of the fouling layer and membrane integrity [61]. Additionally, limited data is available on fouling and performance of different FO membrane materials and only few studies have compared the fouling and performance of commercially available FO membranes $[36,62]$.

Thus, the main objective of the current study was to investigate and compare the performance and fouling of commercial cellulose triacetate (CTA) and polyamide thin film composite (TFC) FO membranes treating water from two different continuously operated activated sludge treatment systems: a low-salinity MBR and a high-salinity OMBR. The objectives of the study were to (1) evaluate and compare CTA and TFC membrane performance over 100-days of biological wastewater operation, (2) examine physiochemical membrane property changes, and (3) investigate the effects of feed stream salinity on FO membrane fouling and performance.

\section{Materials and Methods}

FO membrane performance (water flux and reverse salt flux (RSF)) and fouling were studied with CTA and TFC membranes using a field-operated membrane fouling system treating highsalinity activated sludge from a hybrid ultrafiltration OMBR (UFO-MBR) and low-salinity activated sludge from a sequencing batch MBR (SB-MBR) over 100-days. The UFO-MBR and SB-MBR were continuously fed with municipal wastewater and were located at the Water Reclamation Research Facility of the Colorado School of Mines in Golden, Colorado. Additional laboratory bench-scale experiments were conducted and several membrane characterization techniques were used to study the performance and physiochemical characteristics of the FO membranes before and after long-term fouling tests. 


\subsection{Pilot-Scale Test Systems}

\subsection{1. $U F O-M B R$}

High-salinity feed was provided by a continuously operated UFO-MBR described in a previous publication [1]. The UFO-MBR system consists of an anoxic tank to remove nitrate, a UF unit to extract nutrients and ions, an aerobic tank to oxidize ammonia, a submerged FO membrane cassette, and an RO system for high-quality water production and DS reconcentration. The total dissolved solids (TDS) concentration of the activated sludge in the anoxic and aerobic tanks was maintained at approximately 4,200 mg/L by adjusting the UF permeate flowrate. The ion concentrations in the UFO-MBR process tanks are summarized in Table 1.

\subsection{2. $S B-M B R$}

Activated sludge from the SB-MBR was used to supply low-salinity feed to the FO membrane fouling system. The SB-MBR is composed of two sequencing batch reactors (SBR) and two membrane tanks, described in detail elsewhere [63]. Carbon, phosphorus, and nitrogen are removed in the SBR by aeration cycles that control aerobic and anoxic conditions in the bioreactors. Wastewater treated in the SBR is recirculated from the reactors to two paralleloperated membrane tanks containing $74 \mathrm{~m}^{2}$ of hollow-fiber UF membranes (37 $\mathrm{m}^{2}$ per tank) that extract water from the activated sludge. The average TDS concentration of the UF permeate was approximately $300 \mathrm{mg} / \mathrm{L}$ over the testing period. Concentrations of individual ions measured during the study are also summarized in Table 1.

Table 1. Average dissolved ion concentrations (mg/L) in the UFO-MBR and SBMBR over the experimental period

\begin{tabular}{lrr}
\hline & UFO-MBR & \multicolumn{2}{c}{ SBMBR } \\
\hline Analyte & \multicolumn{2}{c}{ Average (mg/L) } \\
\hline Calcium & $125 \pm 53$ & $35.2 \pm 5.2$ \\
Potassium & $34.2 \pm 19$ & $9.99 \pm 2.9$ \\
Magnesium & $40.3 \pm 17$ & $10.0 \pm 1.8$ \\
Sodium & $1083 \pm 544$ & $53.8 \pm 9.9$ \\
Phosphorus & $12.5 \pm 7.9$ & $2.51 \pm 0.9$ \\
Sulfur & $107 \pm 49$ & $26.0 \pm 5.4$ \\
Silica & $17.0 \pm 7.2$ & $4.95 \pm 0.8$ \\
Fluoride & $5.30 \pm 7.5$ & $0.75 \pm 0.6$
\end{tabular}




\begin{tabular}{|c|c|c|}
\hline & UFO-MBR & SBMBR \\
\hline Analyte & \multicolumn{2}{|c|}{ Average (mg/L) } \\
\hline Chloride & $2292 \pm 1339$ & $72.5 \pm 12$ \\
\hline Bromide & $0.21 \pm 0.3$ & $0.03 \pm 0.03$ \\
\hline Nitrate & $142 \pm 91$ & $30.5 \pm 10$ \\
\hline Phosphate & $42.7 \pm 35$ & $8.41 \pm 2.1$ \\
\hline Sulfate & $331 \pm 150$ & $79.4 \pm 23$ \\
\hline Total & 4232.0 & 334.0 \\
\hline
\end{tabular}

\subsection{Membranes}

CTA and TFC membranes were acquired from Hydration Technology Innovations, LLC (Albany, OR). Membranes were mounted in custom-made cross-flow membrane cells with an effective membrane area of $190 \mathrm{~cm}^{2}$ each. The dimensions of the feed and DS flow channels were 25.4 × $7.62 \times 0.24 \mathrm{~cm}$ and $25.4 \times 7.62 \times 0.16 \mathrm{~cm}$, respectively. All field and laboratory bench-scale tests were conducted with the active layer of the membranes facing the feed. Tricot fine-mesh spacers were placed in the DS flow channel to provide turbulence enhancement and mechanical support, and the feed channels were operated without spacers.

\subsection{Virgin membrane integrity testing}

Membrane performance and integrity were evaluated using water flux and RSF tests were conducted with field and laboratory systems. Water flux was calculated from the change in permeated water volume from the feed per unit membrane area per time $\left(\mathrm{L} / \mathrm{m}^{2} / \mathrm{hr}\right)$. RSF was calculated from the change in salt mass in the feed per unit membrane area per time $\left(\mathrm{g} / \mathrm{m}^{2} / \mathrm{hr}\right)$. Additionally, specific reverse salt flux (SRSF) (mg/L) was calculated from the ratio of RSF to water flux for all virgin and fouled membranes. SRSF is a parameter related to membrane efficiency and depends on active layer selectivity $[64,65]$.

Integrity tests were conducted on virgin membranes before the beginning of the fouling experiment to ensure that membranes were free of defects. Water flux, RSF, and SRSF were measured and virgin membranes with SRSF less than $1,000 \mathrm{mg} / \mathrm{L}$ were installed in the membrane fouling system. The integrity tests were conducted on a laboratory bench-scale system described in previous publications [16, 64, 66]. Data was collected (i.e., feed volume change) and temperature was controlled (i.e., system temperature of $20{ }^{\circ} \mathrm{C}$ ) using data acquisition and instrument control system (LabJack, UE9-Pro, Lakewood, CO) and software (LabVIEW, 
National Instruments Corp., Austin, TX). The feed tank was filled with $3 \mathrm{~L}$ of $2 \mathrm{~g} / \mathrm{L} \mathrm{NaCl}$ and dosed with deionized water to maintain constant volume. Feed conductivity was measured using a handheld probe (Oakton Instruments, Vernon Hills, IL) and was converted to $\mathrm{NaCl}$ concentration to calculate RSF. The DS was $1 \mathrm{~L}$ of $1 \mathrm{M} \mathrm{NaCl}$ and was allowed to dilute, similar to the operation during flux tests in the membrane fouling system (described in Section 2.2.5). The flows for feed and DS were co-current and feed and DS cross-flow velocities were 1,000 and $640 \mathrm{~mL} / \mathrm{min}$, respectively, to maintain a flow velocity of $0.25 \mathrm{~m} / \mathrm{s}$ [67].

\subsection{Membrane fouling experiments: set-up and procedure}

\subsubsection{Membrane fouling system}

Virgin membranes were installed in the membrane fouling system and operated continuously for 100 days. The membrane fouling system was comprised of 12 cross-flow membrane cells, two feed peristaltic pumps (Cole-Palmer, Vernon Hills, IL), one DS peristaltic pump, and one DS tank. Activated sludge from the adjacent UFO-MBR and SB-MBR systems provided highsalinity and low-salinity feed solutions, respectively, and $0.5 \mathrm{M} \mathrm{NaCl}$ was used as the DS. The feed and DS flow were countercurrent and the feed and DS flow rates were maintained at 600and $310 \mathrm{~mL} / \mathrm{min}$, respectively. A picture and schematic drawing of the membrane fouling system are illustrated in Fig. 1.

The 12 cross-flow membrane cells were separated into four groups (three membrane cells per group) based on membrane type (CTA or TFC) and origin of activated sludge: CTA membrane with low-salinity activated sludge feed (“CTA-LS”), CTA membrane with high-salinity activated sludge feed (“CTA-HS”), TFC membrane with low-salinity activated sludge feed (“TFC-LS”), and TFC membrane with high-salinity activated sludge feed (“TFC-HS”). The membrane cells were operated in series within each group; thereby, the feed and DS exiting the first cell in the group fed the second cell, and the feed and DS exiting the second cell in the group fed the third cell. Membrane cells operated for 10, 40, 70, and 100-days. At the beginning of the experiment, the membrane fouling system was operated with twelve membranes cells online. One membrane cell was removed from each group after 40, 70, and 100-days of continuous operation. After removing one membrane cell from each group on day 40, a new virgin membrane cell was installed into each group and operated for 10-days before being removed from the system. 

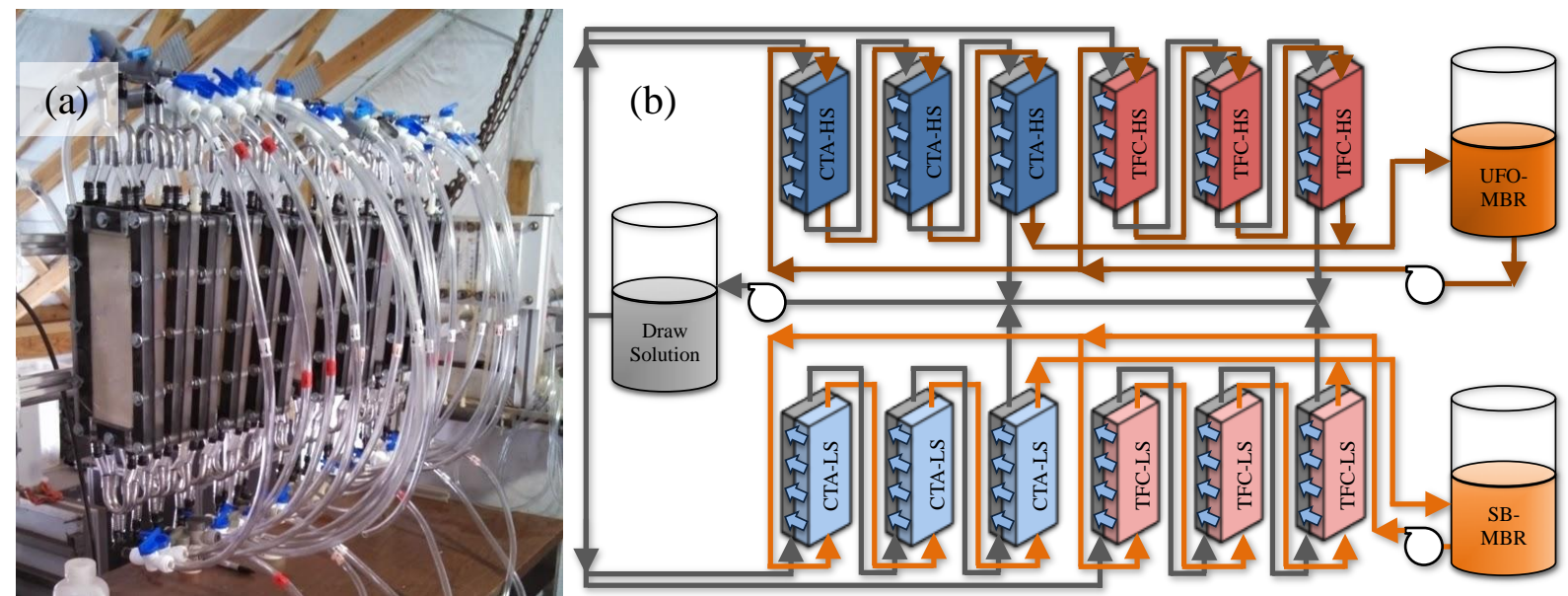

Fig. 1. (a) a picture and (b) a schematic drawing of the membrane fouling system. The SB-MBR provided low-salinity (LS) activated sludge to CTA ("CTA-LS") and TFC ("TFC-LS") membranes, and the UFO-MBR provided high-salinity activated sludge to CTA ("CTA-HS") and TFC ("TFC-HS") membranes. Membranes were arranged in four groups and operated in series within each group. One tank provided draw solution (DS) to all four groups. Feed and DS flows operated co-currently. Arrows represent water flux from the feed solutions to the DS.

\subsubsection{Membrane fouling system measurements}

The UFO-MBR activated sludge, SB-MBR activated sludge, and DS were measured daily for conductivity, $\mathrm{pH}$, and temperature using a handheld meter (Oakton Instruments, Vernon Hills, IL). Daily measurements were used to ensure steady-state feed was supplied to the membrane fouling system and to monitor the DS conductivity, which was diluted in the batch mode operation used in this study. The DS tank was drained and replenished with $0.5 \mathrm{M} \mathrm{NaCl}$ solution when the DS conductivity reached $10 \mathrm{mS}(0.1 \mathrm{M} \mathrm{NaCl})$. The DS conductivity was always higher than the UFO-MBR and SB-MBR activated sludge conductivity to ensure osmotic backwashing and fouling layer removal did not occur.

On a weekly basis, samples were collected from the influent, the UFO-MBR (anoxic tank, aerobic tank, and UF permeate), and the SB-MBR (SBRs, membrane tanks, and UF permeate). Samples were analyzed for nutrients (ammonia, nitrate, total nitrogen, total phosphorus, and chemical oxygen demand (COD)), solids (mixed liquor suspended solids (MLSS) and mixed liquor volatile suspended solids (MLVSS)), cations, and anions. Nutrient concentrations were measured using Hach TNTplusTM (Loveland, CO) reagent vials and Hach DR 5000TM spectrophotometer. DS samples were diluted with deionized water to ensure that sodium and chloride concentrations were within analytical limits. MLSS and MLVSS analysis was 
conducted using standard glass fiber filters according to Standard Method 2540. Ions were measured in the UF permeate from the SB-MBR and UFO-MBR in order to characterize the feed streams. Anion concentrations were measured using an ion chromatograph (IC) (ICS-90, Dionex, Sunnyvale, CA) and cations were measured using an inductively coupled plasma atomic emission spectroscopy (ICP-AES) (Optima 5400, PerkinElmer, Fremont, CA). ICP-AES samples were acidified to a $\mathrm{pH}$ of less than 2 with nitric acid.

\subsubsection{Membrane fouling system water flux testing}

Weekly water flux tests were conducted for each membrane in the membrane fouling system using system equipment (e.g., peristaltic pumps, cross-flow membrane cells) in order to observe the effects of fouling on water flux. Activated sludge from the two MBRs was used as the feed during the field water flux tests to prevent disturbance or removal of the developed fouling layers. Water flux tests were conducted using $1 \mathrm{M} \mathrm{NaCl}$ DS that was allowed to dilute over a 90minute testing period. The feed and DS flow direction (co-current) and flow rates were consistent with the virgin membrane integrity tests (described above) to allow for comparisons between virgin and weekly water flux results.

\subsection{Fouled membrane integrity testing}

The membranes were removed from the membrane fouling system after the predetermined number of days (10, 40, 70, and 100 days) and water flux, RSF, and SRSF were measured. After the membranes were removed from the membrane fouling system cells, a coupon was cut from the fouled membrane and installed into a smaller custom cross-flow membrane cell. The smaller cell had symmetrical feed and DS flow channels $(21.91 \times 5.40 \times 0.32 \mathrm{~cm})$ and an effective membrane area of $120 \mathrm{~cm}^{2}$. Experiments were performed on the laboratory bench-scale system using the same cross-flow velocities, DS concentrations, and feed and DS temperatures used for the virgin membrane integrity tests.

\subsection{Membrane Characterization}

\subsubsection{Contact Angle}

Contact angle measurements were taken to quantify hydrophilicity for virgin CTA and TFC membranes. Contact angles were measured using the captive bubble method with a computerized 
goniometer (Model 200-00, Rame-Hart Instrument Company, Netcong, NJ). Two coupons per membrane were sampled and were immersed in deionized water, placed on the goniometer stage, and a $5 \mu \mathrm{L}$ air bubble was pipetted onto the membrane active layer. Three bubbles per coupon were analyzed with 30 measurements per bubble.

\subsubsection{Environmental scanning electron microscopy and energy dispersive X-ray spectroscopy}

Virgin and fouled membrane cross-sections and surfaces were visually examined for damage and fouling with an environmental scanning electron microscope (ESEM) (Quanta 600, FEI, Tokyo, Japan). Fouled membrane coupons were prepared for ESEM through immersion in Karnovsky's fixative; dehydration with a graded series of ACS grade ethanol; and storage in a desiccator until analysis. Membranes were fractured with liquid nitrogen and gold-sputtered (Technic Hummer VI, Cranston, RI) before analysis. In conjunction with ESEM, energy dispersive X-ray spectroscopy (EDS) (Genesis, EDAX, Mahwah, NJ) was used to determine the elemental content of inorganic deposits attached to the membrane surface. ESEM micrographs of the virgin CTA and TFC membrane surfaces and cross-sections are shown in Fig. 2.

\subsubsection{Fourier transform infrared spectrometer}

To identify organic foulants and surface chemistry changes, the fouling and active layers of virgin and fouled membranes were analyzed with a Fourier transform infrared (FTIR) spectrometer (Nicolet 4700 FTIR, Thermo Electron Corporation, Madison, WI) using the attenuated total reflection method. Virgin and fouled membrane coupons were prepared for FTIR analysis by drying in a desiccator for at least 24 hours before analysis. 


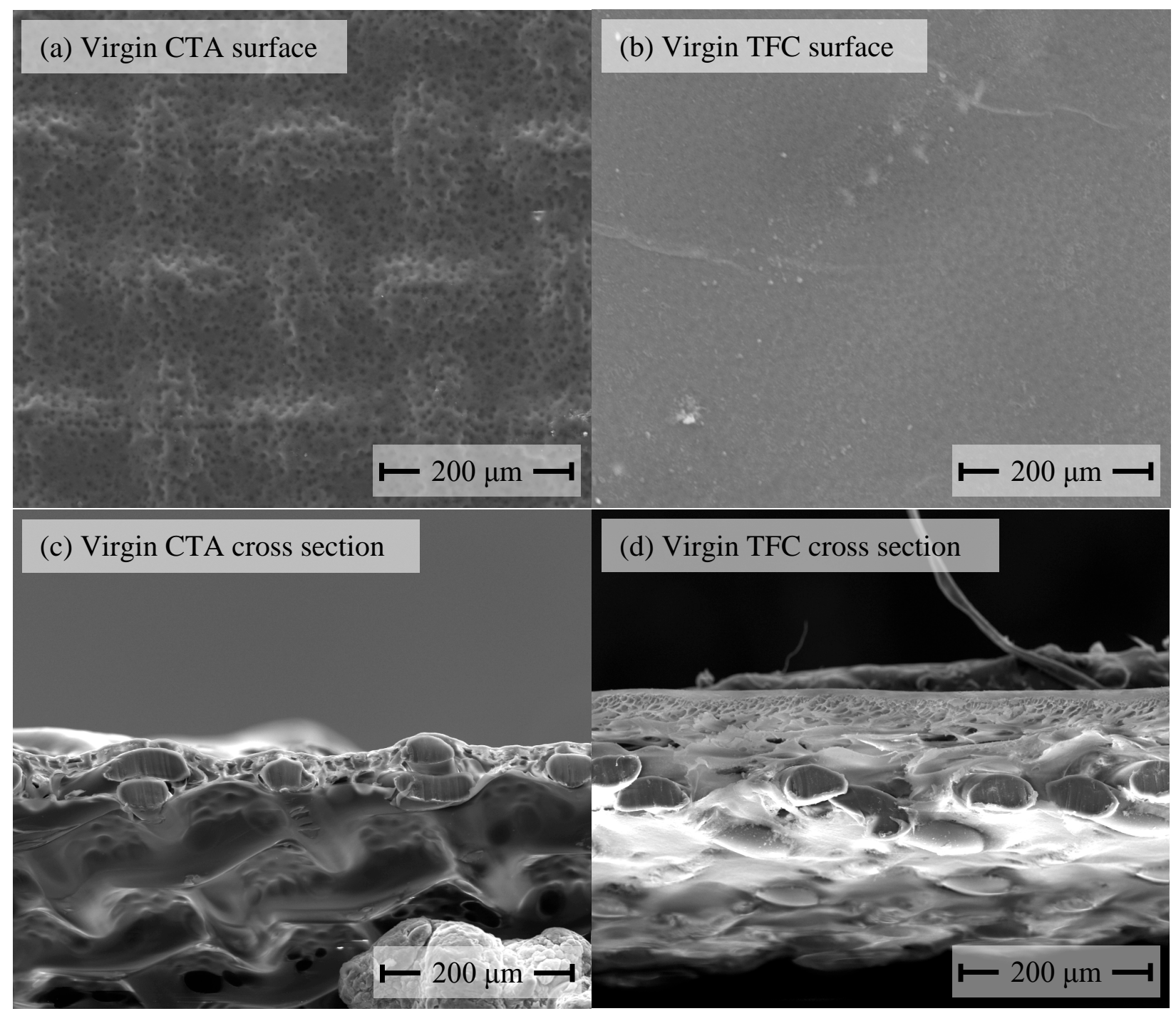

Fig. 2. ESEM micrographs (250x magnification) of the (a) surface (separation layer) of the virgin CTA membrane, (b) surface of the virgin TFC membrane, (c) cross section of the virgin CTA membrane, and (d) cross section of the virgin TFC membrane. In (a) and (b) the separation layer is on top.

\section{Results and Discussion}

\subsection{Performance of membrane bioreactors}

The UFO-MBR and SB-MBR influent, process tanks, and effluent were regularly analyzed for MLSS, MLVSS, $\mathrm{pH}$, conductivity, and temperature to ensure that steady-state feed was provided to the FO membrane fouling system over the testing period. The overall MBR performance was also assessed using the percent removals of COD, total phosphorous (TP), and 
total nitrogen (TN) between the influent and effluent of each system. The results from these analyses are summarized in Table 2.

Table 2. The average mixed liquor suspended solids (MLSS) concentration, mixed liquor volatile suspended solids (MLVSS) concentration, $\mathrm{pH}$, conductivity, temperature, and percent removal of COD, TN, and TP concentrations in the UFO-MBR and SB-MBR over the experimental period

\begin{tabular}{|c|c|c|c|c|c|c|}
\hline \multirow[b]{2}{*}{ Analyte } & \multirow[b]{2}{*}{ Unit } & \multirow[b]{2}{*}{ Influent } & \multicolumn{2}{|c|}{ UFO-MBR } & \multicolumn{2}{|c|}{ SB-MBR } \\
\hline & & & $\begin{array}{l}\text { Anoxic } \\
\text { Tank }\end{array}$ & $\begin{array}{c}\text { Aerobic } \\
\text { Tank }\end{array}$ & $\begin{array}{l}\text { Bio- } \\
\text { reactors }\end{array}$ & $\begin{array}{c}\text { Membrane } \\
\text { Tanks }\end{array}$ \\
\hline MLSS & $\mathrm{g} / \mathrm{L}$ & $0.14 \pm 0.02$ & $1.21 \pm 0.7$ & $1.53 \pm 1.0$ & $5.05 \pm 1.5$ & $6.28 \pm 1.9$ \\
\hline MLVSS & $\mathrm{g} / \mathrm{L}$ & $0.13 \pm 0.03$ & $1.18 \pm 0.7$ & $1.48+1.0$ & $4.74 \pm 1.3$ & $5.85 \pm 1.6$ \\
\hline $\mathrm{pH}$ & - & -- & $7.30 \pm 0.9$ & $7.24 \pm 0.8$ & -- & $7.04 \pm 0.8$ \\
\hline Conductivity & $\mathrm{mS} / \mathrm{cm}$ & -- & $5.85 \pm 2.3$ & $6.59 \pm 2.5$ & -- & $0.61 \pm 0.2$ \\
\hline \multirow[t]{2}{*}{ Temperature } & ${ }^{\circ} \mathrm{C}$ & -- & $21.7 \pm 3.1$ & $22.8 \pm 3.2$ & -- & $21.1 \pm 2.1$ \\
\hline & & & Effluent & \% Removal & Effluent & \% Removal \\
\hline COD & $\mathrm{mg} / \mathrm{L}$ & $392 \pm 83$ & $6.98 \pm 3.8$ & $98.1 \pm 1.1 \%$ & $15.5 \pm 3.5$ & $95.9 \pm 1.1 \%$ \\
\hline $\mathrm{TP}$ & $\mathrm{mg} / \mathrm{L}$ & $13.0 \pm 1.4$ & $0.03 \pm 0.03$ & $99.8 \pm 0.3 \%$ & $7.08 \pm 3.0$ & $45.1 \pm 22 \%$ \\
\hline $\mathrm{TN}$ & $\mathrm{mg} / \mathrm{L}$ & $42.2 \pm 7.3$ & $4.76 \pm 4.2$ & $88.2 \pm 11 \%$ & $4.12 \pm 2.1$ & $87.4 \pm 11 \%$ \\
\hline
\end{tabular}

The UFO-MBR and SB-MBR operation was stable over the testing period and within normal operating conditions determined in previous system-specific studies [1,63]. The measured $\mathrm{pH}$ and temperature were similar in the two systems during the fouling study, and COD, TP, and TN removals were consistent with literature $[1,63]$. COD, TP, and TN removals were higher in the UFO-MBR than in the SB-MBR because the nonporous FO membranes had superior rejection of dissolved constituents (e.g., $\mathrm{NO}_{3}{ }^{-}, \mathrm{PO}_{4}{ }^{3-}$ ) than the porous SB-MBR UF membranes. The conductivity and TDS concentration were higher in the UFO-MBR per the experimental design and were achieved through low UF permeate rates and high TDS rejection by the FO membranes. MLSS and MLVSS concentrations in the SB-MBR and UFO-MBR were representative of steady-state conditions at the required HRT and SRT; it is important to note that MLSS and MLVSS concentrations were much higher in the SB-MBR than in the UFOMBR. Differences in salinity and MLSS concentrations between the high-salinity and lowsalinity FO feed were used to examine the influence of feed composition on FO fouling. 


\subsection{Virgin membrane integrity results}

CTA and TFC membranes were measured for water flux and RSF before installation in the membrane fouling system to ensure that there were no membrane defects. The measured water flux and RSF values were used to calculate the SRSF, and only membranes with an SRSF less than $1,000 \mathrm{mg} / \mathrm{L}$ were installed in the membrane fouling test system. The average measured water flux, RSF, SRSF, contact angle, and surface roughness for the CTA and TFC membranes are summarized in Table 3.

Table 3. Virgin membrane properties, including water flux, reverse salt flux (RSF), specific reverse salt flux (SRSF), contact angle, and surface roughness

\begin{tabular}{lccccc}
\hline & Water Flux & RSF & SRSF & $\begin{array}{c}\text { Contact } \\
\text { angle }\end{array}$ & $\begin{array}{c}\text { Roughness } \\
\left(\mathrm{R}_{\mathrm{a}} / \mathrm{R}_{\mathrm{q}}\right)^{\mathrm{b}}\end{array}$ \\
\cline { 2 - 6 } & $\mathrm{L} / \mathrm{m}^{2} / \mathrm{hr}$ & $\mathrm{g} / \mathrm{m}^{2} / \mathrm{hr}$ & $\mathrm{mg} / \mathrm{L}$ & ${ }^{\circ}$ & $\mathrm{nm}$ \\
\hline CTA & $8.6 \pm 1.4$ & $5.5 \pm 1.4$ & $655 \pm 210$ & $48.2 \pm 3.5$ & $23.4 / 29.5^{\mathrm{a}}$ \\
TFC & $11.7 \pm 1.2$ & $4.8 \pm 0.9$ & $422 \pm 96$ & $12.9 \pm 2.1$ & $23.1 / 28.6^{\mathrm{a}}$ \\
\hline
\end{tabular}

${ }^{\mathrm{a}}$ Values from previous publication [62].

burface roughness was analyzed with atomic force microscopy and results are reported as average roughness $\left(\mathrm{R}_{\mathrm{a}}\right)$ and root mean square roughness $\left(\mathrm{R}_{\mathrm{q}}\right)$.

Virgin TFC membranes had higher water flux, lower RSF, and lower SRSF than the CTA membranes, which is in agreement with literature values [36, 62]. Lower SRSF is a desirable membrane property that allows for high water flux and low solute diffusion. TFC membranes also had lower contact angles and equivalent surface roughness to CTA membranes. The lower contact angle for virgin TFC membranes indicated a more hydrophilic membrane, which is widely considered as a beneficial membrane property to reduce fouling propensity [25, 30, 31].

\subsection{Membrane fouling system water flux results}

Water flux was measured weekly using the membrane fouling system to evaluate CTA and TFC membrane performance treating two different activated sludge streams over the 100-day testing period. Water flux measurements were conducted using activated sludge from the UFOMBR and SB-MBR with high-salinity and low-salinity feed streams, respectively. The DS used for water flux tests was a 1-M NaCl solution. The measured water flux was averaged within each membrane group (i.e., CTA-HS, CTA-LS, TFC-HS, and TFC-LS). The average water flux and 
FS temperature over the 100-day testing period for each membrane group and sludge type is shown in Fig. 3.

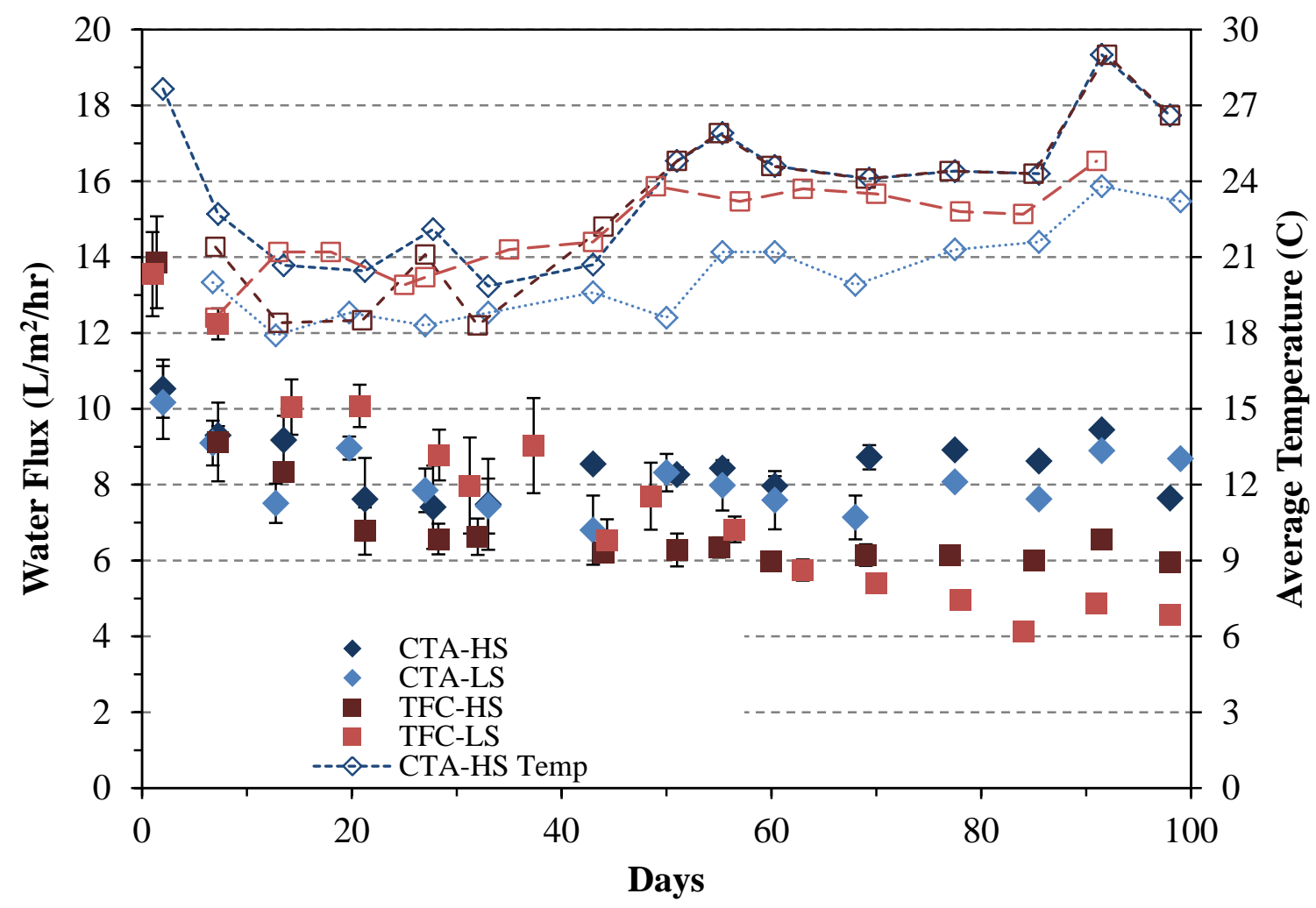

Fig. 3. Water flux results from the membrane fouling system over the 100-day experiment. Results are shown for CTA-HS, CTA-LS, TFC-HS, and TFC-LS membranes. Water flux results after day 70 do not have error bars because standard error cannot be calculated with one membrane. Dashed lines indicate average temperature $\left({ }^{\circ} \mathrm{C}\right)$ for each membrane group over 100 days.

Initial water fluxes for CTA-HS and CTA-LS membranes were 10.5 and $10.2 \mathrm{~L} / \mathrm{m}^{2} / \mathrm{hr}$, respectively, and initial water fluxes for TFC-HS and TFC-LS membranes were 13.9 and 13.6 $\mathrm{L} / \mathrm{m}^{2} / \mathrm{hr}$, respectively. The initial water flux (Fig. 3) for each membrane tested in the membrane fouling system were higher than the corresponding virgin water flux (Table 3) because the field water flux tests were conducted at higher temperatures (i.e., average of $25.6^{\circ} \mathrm{C}$ ) than the virgin integrity tests (i.e., $20{ }^{\circ} \mathrm{C}$ ). However, when the water fluxes were corrected to $25{ }^{\circ} \mathrm{C}$, the temperature corrected water flux for the membrane fouling system was 10.2 and $13.5 \mathrm{~L} / \mathrm{m}^{2} / \mathrm{hr}$ for CTA and TFC membranes, respectively, and the temperature corrected water flux was 10.0 and 
13.6 $\mathrm{L} / \mathrm{m}^{2} / \mathrm{hr}$ for virgin CTA and TFC membranes, respectively. Thus, the temperature corrected field and virgin initial water fluxes were in agreement.

The water flux decreased over the testing period for all membranes studied and was characterized by an initial decline and subsequent steady-state period. The water flux decreased during the first 27 days and stabilized at approximately $8.2 \mathrm{~L} / \mathrm{m}^{2} / \mathrm{hr}$ for CTA membranes, and water flux decreased over 60 days and stabilized at approximately $5.3 \mathrm{~L} / \mathrm{m}^{2} / \mathrm{hr}$ for TFC membranes. The flux decline and steady-state periods are similar to those described in other FO fouling studies [1, 2, 20, 50]. Zhang et al. [50] operated an OMBR using TFC FO membranes and synthetic municipal wastewater for 55 days. In their study, the water flux decreased over 12 days and stabilized at approximately $3.9 \mathrm{~L} / \mathrm{m}^{2} / \mathrm{hr}$. The authors attributed the initial flux decline and steady-state periods to OMBR salt accumulation and membrane fouling. However, analogous to Holloway et al. [1], the present study did not have salt accumulation in either MBR and flux decline is most likely due to membrane fouling.

The effect of fouling on FO water flux is well documented. Studies have shown that a main contributor to water flux decline in salt-rejecting membranes is cake-enhanced osmotic pressure (CEOP) [22, 53, 68-70]. CEOP is a phenomenon that occurs when salts diffuse from the DS to the feed and accumulate in the fouling layer; the salt accumulation increases the osmotic pressure at the feed-membrane interface and ultimately diminishes water flux. Lee at al. [22] elucidated the importance of CEOP in FO membranes by comparing water flux decline between two DS types. The experiments were conducted with $0.6 \mathrm{M}-\mathrm{NaCl}$ or $5 \mathrm{M}$-dextrose as DS; water flux decreased more severely when using an NaCl DS. The authors concluded that minimal RSF from dextrose resulted in a lesser degree of CEOP and water flux decline. In the present study, the membrane fouling system operated with a similar $\mathrm{NaCl}$ DS (0.5 M) and RSF likely led to CEOP and water flux decline.

TFC membranes were more prone to fouling, which was confirmed by the observed decline in water flux (Fig. 3) and visual inspection of the membranes. Two previous studies also demonstrated higher water flux decline and fouling propensity for TFC versus CTA membranes and attributed the difference to higher initial water fluxes [62] and surface roughness [36]. Recent studies have shown that FO membrane fouling propensity increases with increasing initial water flux due to higher convective flow of foulants to the membrane surface and compaction of fouling layers [37, 71]. Xie at al. [71] demonstrated that the influence of CEOP on 
water flux is more severe for membranes that have a more compact fouling layer. Thus, higher initial water flux for TFC membranes may be responsible for higher fouling propensity and lower steady-state water flux.

\subsection{Fouling layer characterization}

The fouling layers that developed on the CTA and TFC membranes was visually examined using an ESEM and are shown in Fig. 4. The images suggested the prevalence of biofouling and organic fouling, which was substantiated with FTIR analyses of the fouling layers. A comparison of FTIR spectra between virgin and fouled membranes was used to determine the organic composition of the fouling layer and is shown in Fig. 5. Virgin membrane peaks disappeared or were weakened when a fouling layer was present. In the fouling layers, peaks near 2923 and $2852 \mathrm{~cm}^{-1}$ represented aliphatic methylene groups, found in fats and lipids; proteins were indicated by the amide I and amide II peaks at 1637 and $1540 \mathrm{~cm}^{-1}$; and C-O stretching of a polysaccharide was found at approximately $1028 \mathrm{~cm}^{-1}$. The peaks were the same for both membrane and feed types, and corresponded to peptidoglycans found in bacterial cell walls [72]. Overall, FTIR results showed a predominance of biofouling and organic fouling. 

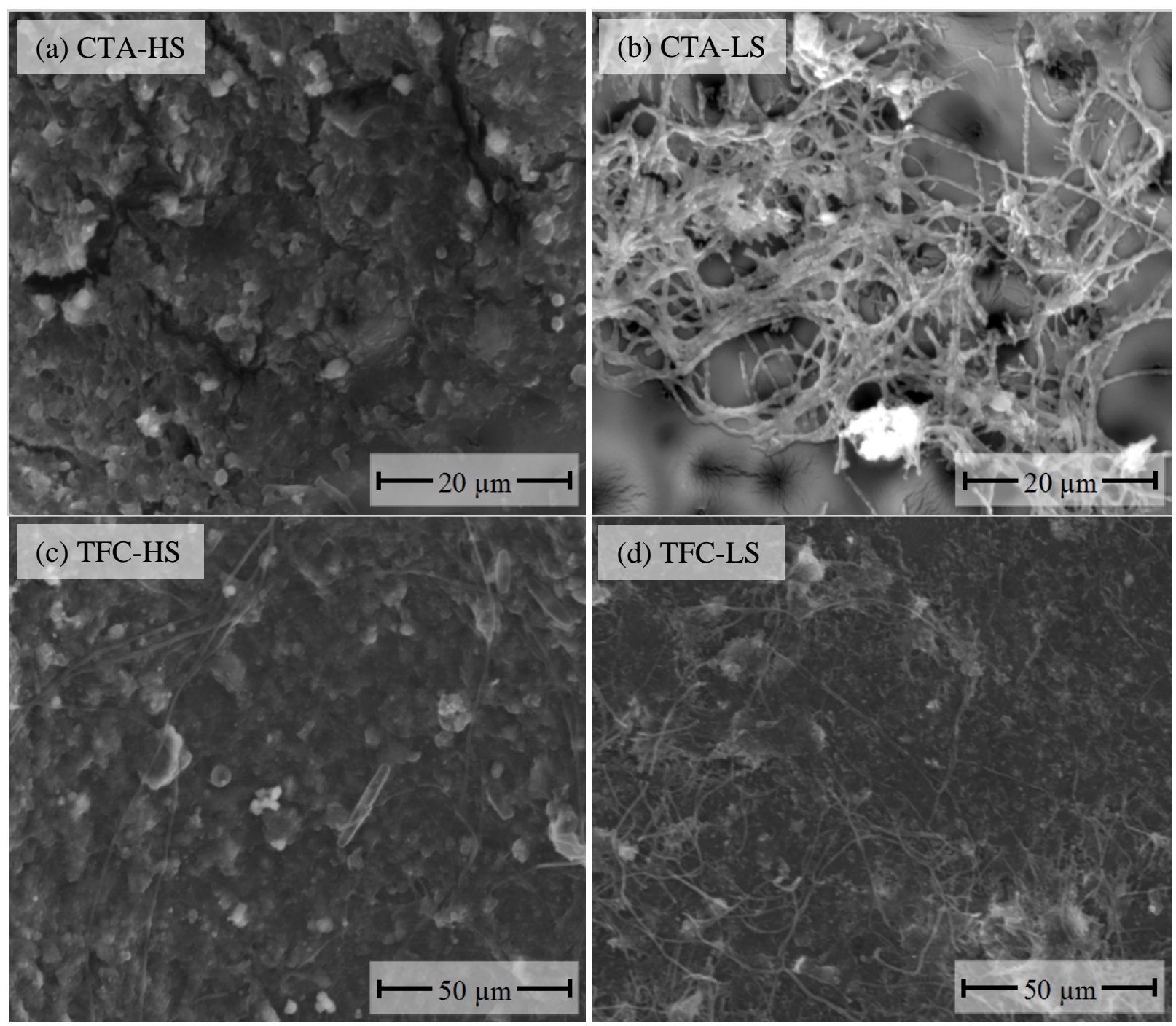

Fig. 4. ESEM micrographs of fouling layers of the (a) CTA-HS (2500x), (b) CTA-LS (2500x), (c) TFC-HS (1000x), and (d) TFC-LS (1000x) membranes. 

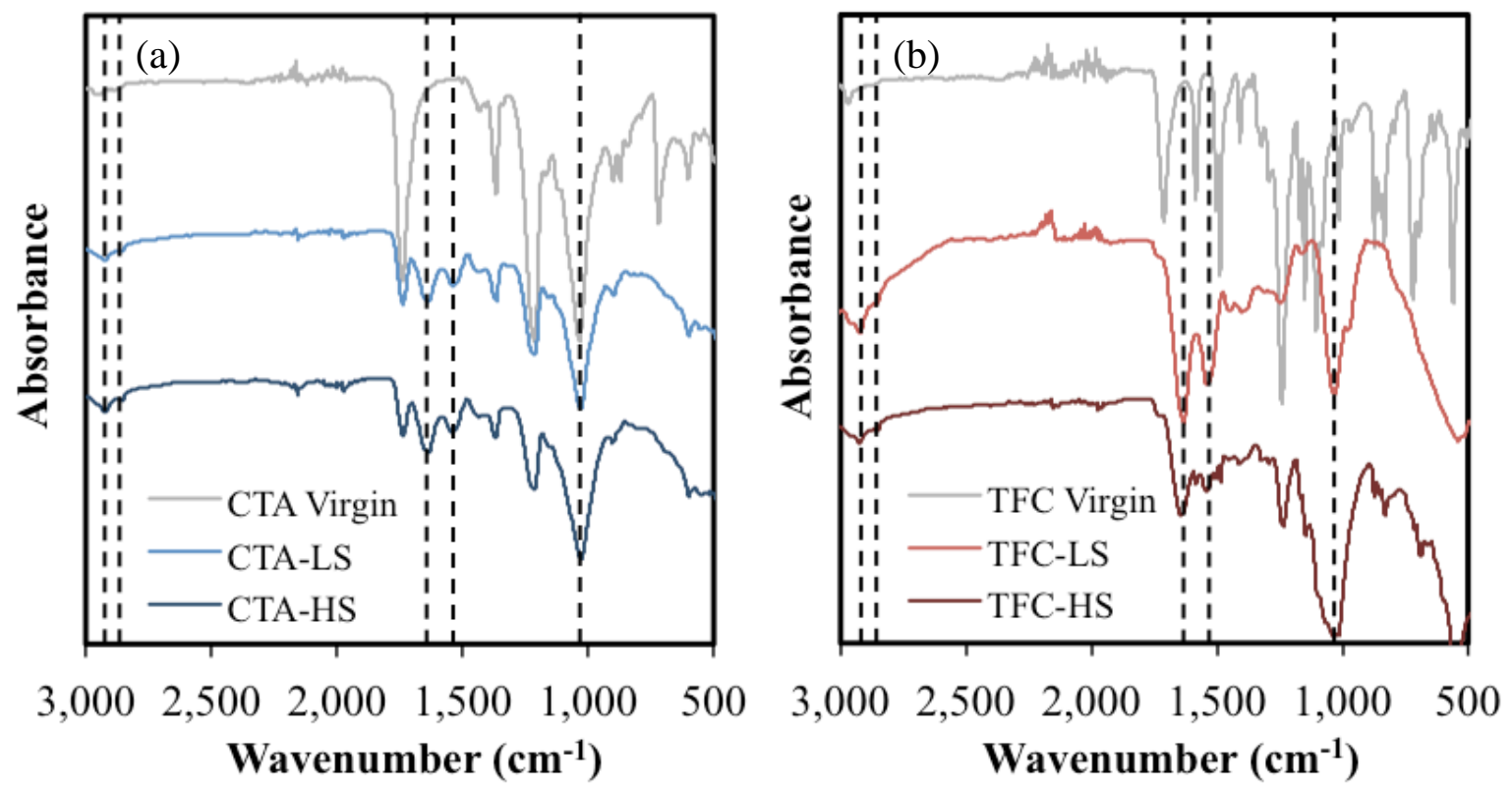

Fig. 5. FTIR spectra of (a) CTA virgin active layer, CTA-LS fouling layer, and CTA-HS fouling layer; and (b) TFC virgin active layer, TFC-LS fouling layer, and TFC-HS fouling layer.

EDS analyses were used to compare the elemental content of the fouling layers (Fig. 6). EDS analyses revealed that fouling layers contained calcium, aluminum, silicon, phosphorus, potassium, sodium, chlorine, and magnesium. High amounts of sulfur were found in the TFC membrane fouling layers and were likely because of their polysulfone support layer. Calcium was more prevalent in CTA-HS and TFC-HS fouling layers. The high-salinity feed had much higher calcium concentrations $(125 \mathrm{mg} / \mathrm{L}$ ) than the low-salinity sludge (35 mg/L) (Table 1); the higher calcium concentrations increased the likelihood of calcium binding to EPS in the biofilm [73]. 


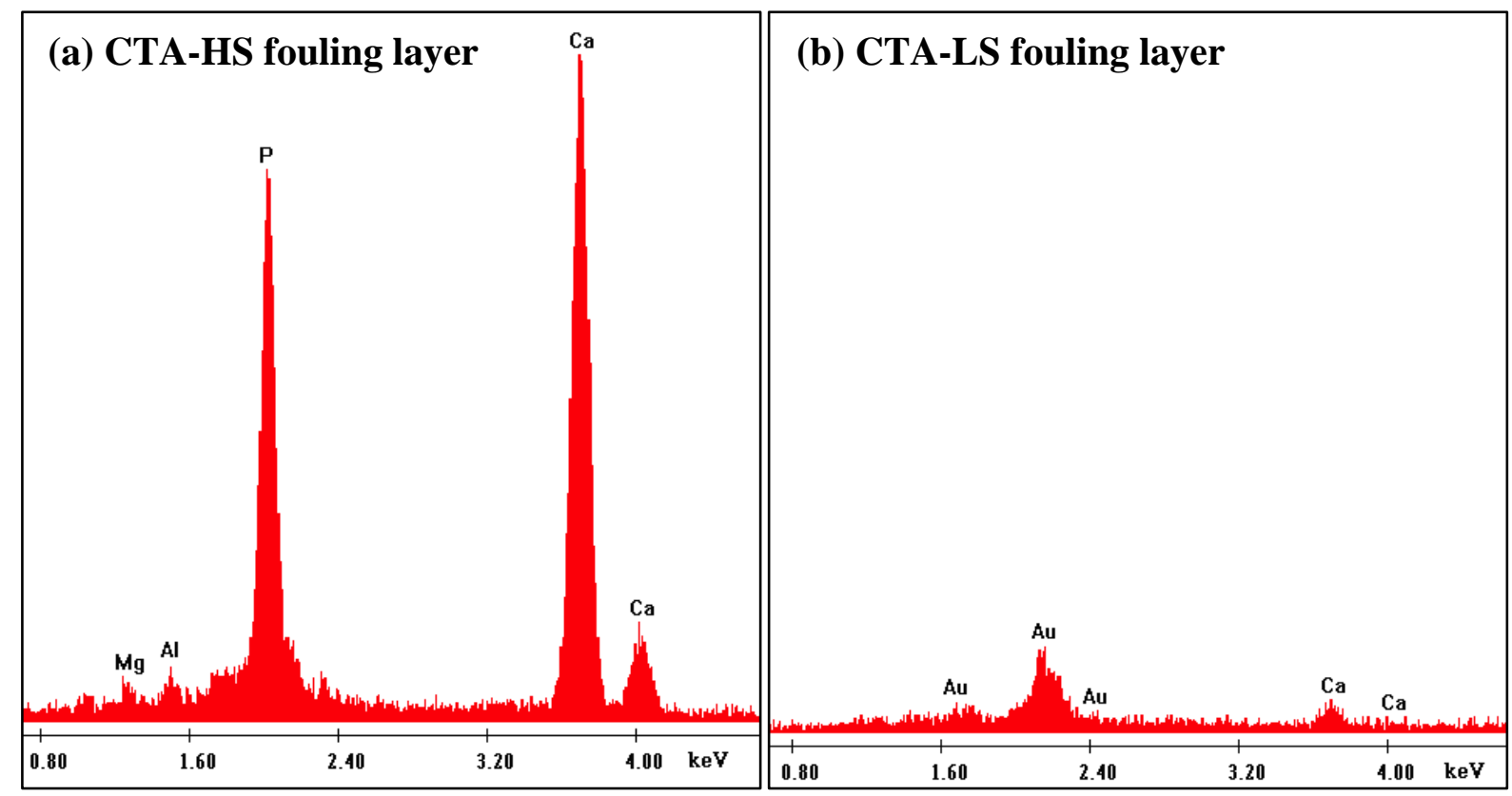

(c) TFC-HS fouling layer

(d) TFC-LS fouling layer
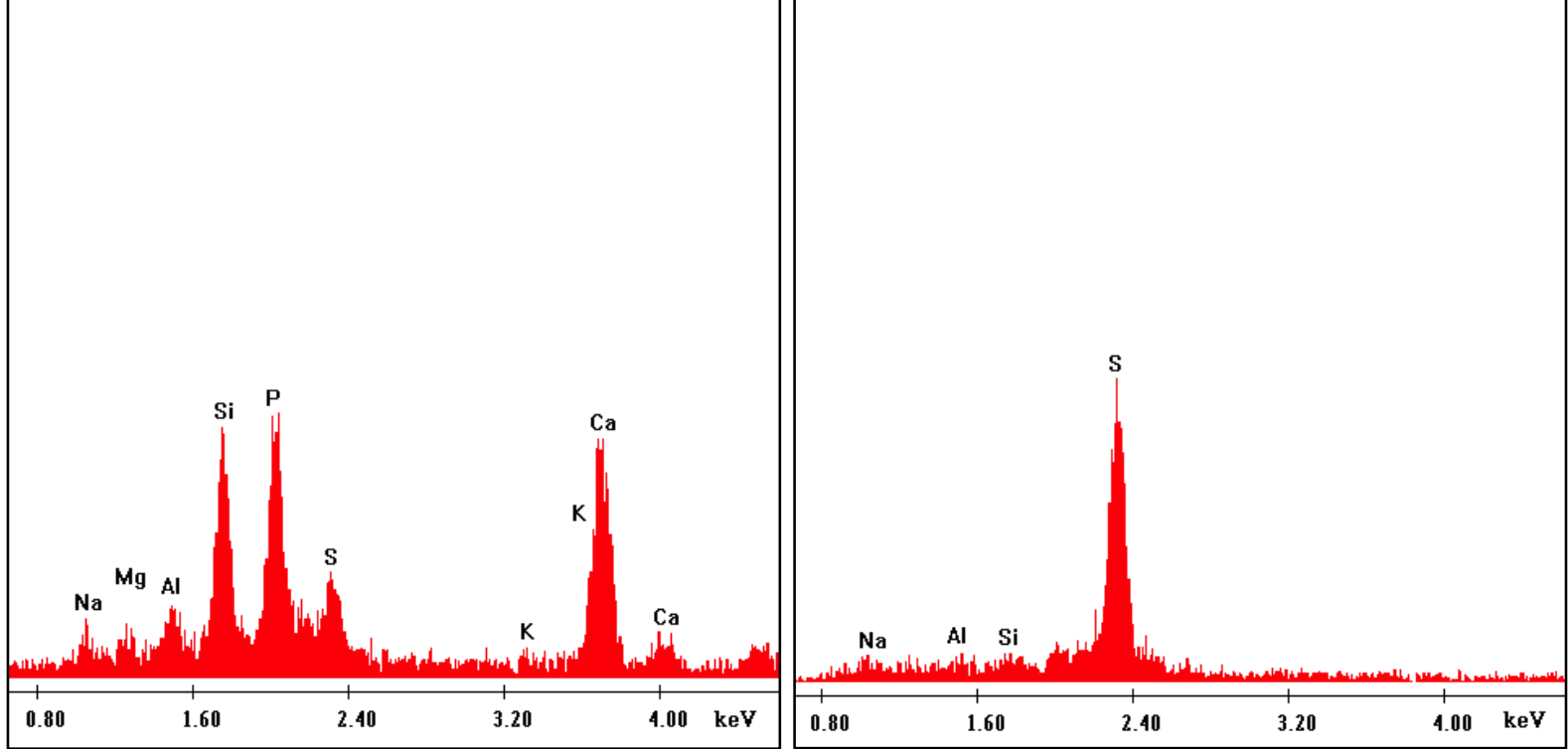

Fig. 6. EDS analyses of fouling layers for (a) CTA-HS, (b) CTA-LS, (c) TFC-HS, and (d) TFCLS membranes.

\subsection{Effects of feed composition on fouling}

Water flux results from the membrane fouling system were used to assess the effects of salinity and MLSS concentrations on fouling propensity. The UFO-MBR provided high-salinity feed for the membrane fouling test system, but with lower MLSS concentrations, and the SBMBR provided a low-salinity feed with higher MLSS concentrations. TDS concentrations were 
approximately 4,200 and $300 \mathrm{mg} / \mathrm{L}$ for the UFO-MBR and SB-MBR, respectively, and MLSS concentrations were approximately 1.5 and $6.3 \mathrm{~g} / \mathrm{L}$, respectively.

Higher ionic strength water has been shown to increase fouling [74] and is thought to reduce foulant charge, foulant-foulant electrostatic repulsion, and foulant-membrane electrostatic repulsion. However, increased salinity and ionic strength did not have an effect on CTA and TFC membrane fouling in the present study. Motsa et al. [29] and van den Brink et al. [75] also found that ionic strength did not worsen fouling and flux decline. The authors suggested that foulantfoulant and foulant-membrane adhesions forces decreased at high ionic strengths in the presence of calcium. This was supported by a previous study that found decreased adhesion forces at increasing ionic strength in the presence of calcium, in which adhesion forces reached a constant value at an ionic strength of $30 \mathrm{mM}$ [76]. The high-salinity and low-salinity activated sludge in the present study had ionic strengths of approximately 140 and $10 \mathrm{mM}$, respectively, and it may be possible that foulant adhesion forces were similar in the two feeds.

Divalent ions (i.e., calcium) are also known to substantially exacerbate membrane fouling and flux decline because of the formation of cross-linked gel layers with organics [20, 36, 37]. Calcium concentrations in the present study were 125 and $35 \mathrm{mg} / \mathrm{L}$ in the high-salinity and lowsalinity feed (Table 1), and resulted in higher amounts of calcium in the CTA-HS and TFC-HS fouling layers (Fig. 6). Despite higher amounts of calcium in the fouling layers (Fig. 6), water flux was comparable between the two feed compositions (Fig. 3) and showed that calcium did not affect water flux. The finding is in agreement with previous studies [29, 43, 54] that attributed the non-effects of calcium to low initial water fluxes [54] and FO membrane resilience [29, 43].

MLSS concentrations also did not affect water flux between the SB-MBR and UFO-MBR (Fig. 3). The finding is contrary to conventional MBR fouling literature [23] but in agreement with two recent publications on FO fouling [77, 78]. This distinction in MLSS concentration effects on conventional and osmotic MBR membrane fouling is elucidated by Luo et al. [77]. High water flux decline was observed for MF at increasing MLSS concentrations ( 0 to $20 \mathrm{~g} / \mathrm{L}$ ), but FO water flux was less affected at the same concentrations. Additionally, the study observed minimal FO water flux decline at MLSS concentrations relevant to the present study and is consistent with a previous study that used concentrations ranging from 5 to $12 \mathrm{~g} / \mathrm{L}$ [78]. These 
FO fouling studies corroborate our water flux results and confirm that FO fouling propensity is low at increasing MLSS concentrations.

\subsection{Effects of membrane properties on fouling}

Contact angle was measured on virgin and fouled membranes to determine if fouling propensity was affected by membrane hydrophilicity. Virgin TFC membranes were much more hydrophilic compared to virgin CTA membranes, with average contact angles of $12.9^{\circ}$ and $48.2^{\circ}$, respectively. In the current study the water flux through the TFC membranes decreased more substantially compared to the water flux through the CTA membranes (Figure 3), illustrating that virgin membrane hydrophilicity is not a reliable indicator for membrane fouling propensity. This result is also supported by several other membrane fouling studies [36, 47, 62].

Membrane hydrophilicity did not affect fouling propensity in this study. One explanation is that contact angle measurements are only representative of the surface energy of the membrane; rather, it is necessary to understand the interaction energies, or adhesive forces, between the membrane and foulants [79]. Several studies have investigated the adhesive forces in surfacefoulant interactions [20, 80, 81]. With regards to biofouling, Ma et al. [81] used atomic force microscopy (AFM) to determine that surface heterogeneity and a small number of highly adhesive sites dictated the extent of bacterial adhesion to metal oxide surfaces. This technique was also used by Mi et al. [20] to compare PA and cellulose acetate (CA) FO membranes fouling using alginate as a model foulant. It was concluded in their study that the heterogenic PA membrane with a small amount of highly adhesive sites had a greater fouling propensity compared to the homogenous CA surface with a higher average adhesion force. Additionally, the foulant-foulant adhesive forces were comparable on the CA and PA membranes, but alginate demonstrated an extensive long-range attraction to the PA membrane beyond the adsorbed fouling layer.

Surface roughness is another often-cited membrane property that is thought to play a dominant role in fouling [36, 37, 82]. Virgin CTA and TFC membranes used in the current study had similar surface roughness (Table 3), and surface roughness was ruled out as a major factor in membrane fouling propensity. However, it is possible that the TFC membranes had an average roughness similar to CTA, but heterogenic roughness on the nanoscale allowed for foulant adsorption and nucleation [83]. Thus, heterogeneity and a small amount of highly adhesive sites 
may have contributed to the higher fouling propensity seen in TFC membranes in the present study.

\subsection{Fouled membrane integrity results}

Integrity tests were conducted on fouled CTA and TFC membranes in order to evaluate the fouling effects on membrane performance (i.e., water flux, RSF, SRSF). Coupons were sampled from each membrane and the lab bench-scale system was used to conduct the integrity tests with $2 \mathrm{~g} / \mathrm{L} \mathrm{NaCl}$ as feed solution and $1 \mathrm{M} \mathrm{NaCl}$ as DS. Water flux, RSF, and SRSF results are shown in Fig. 7 for CTA and TFC membranes fouled for 10, 40, 70, and 100 days.
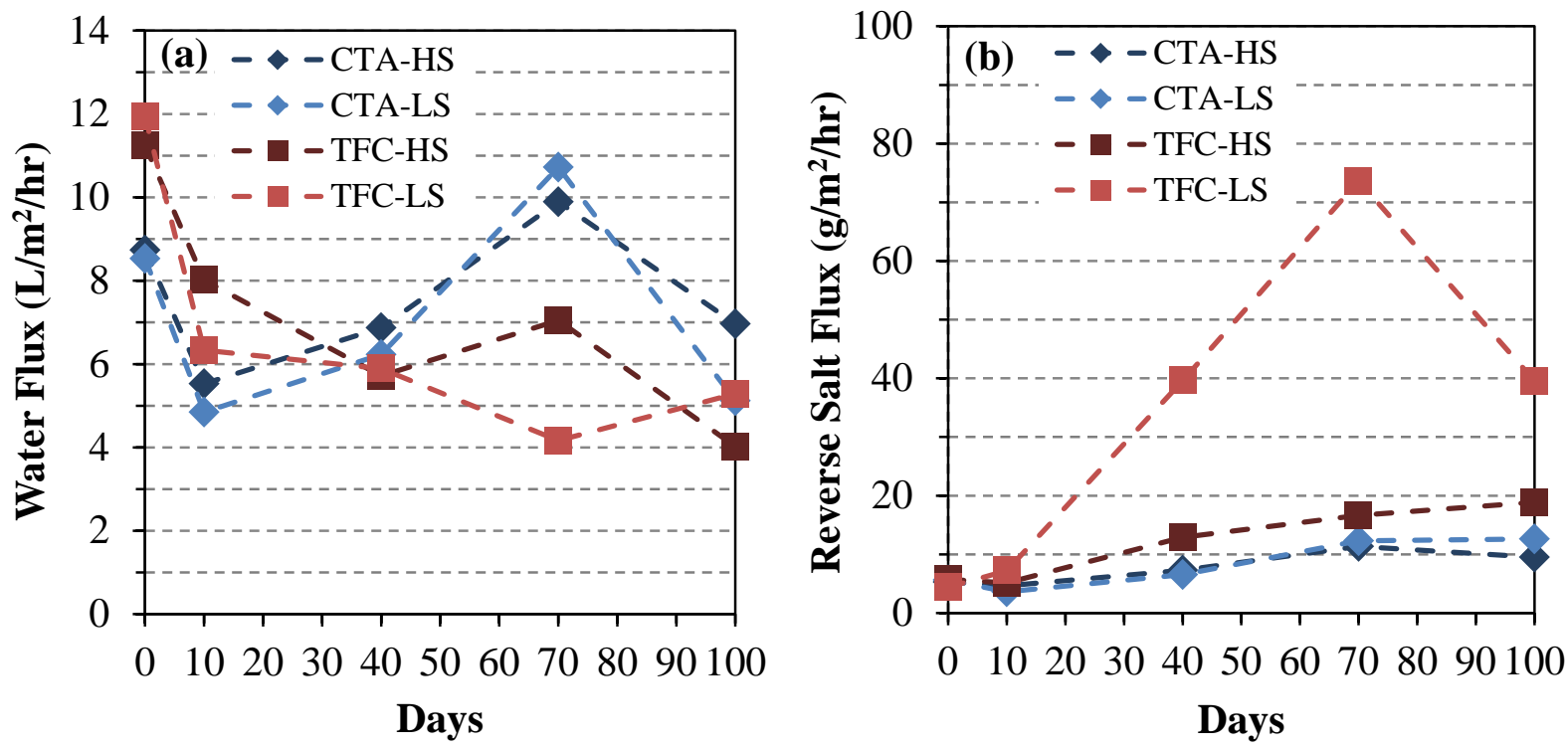


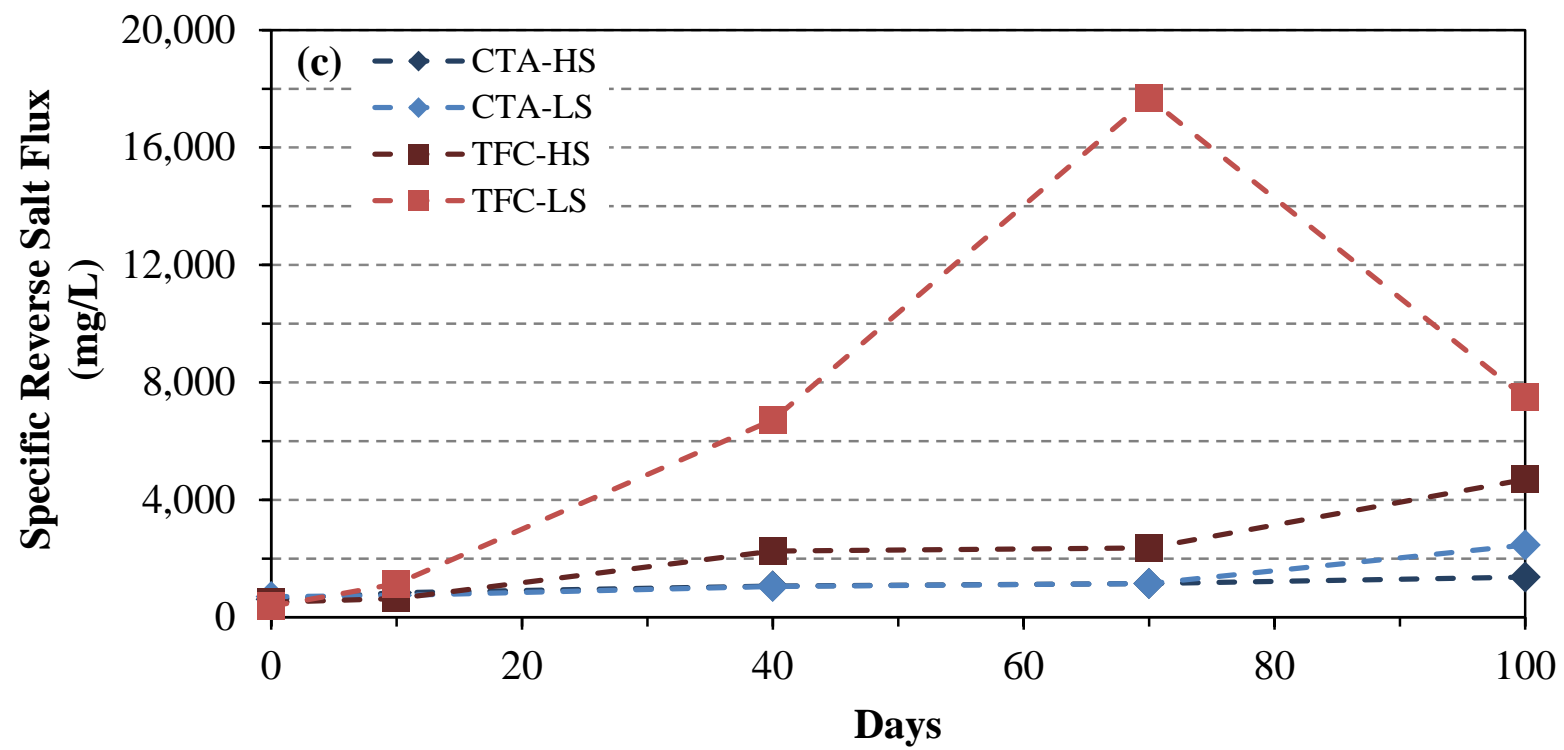

Fig. 7. Membrane integrity results for CTA-LS, CTA-HS, TFC-LS, and TFC-HS after 10, 40, 70 , and 100-days of fouling. Integrity results include (a) water flux $\left(\mathrm{L} / \mathrm{m}^{2} / \mathrm{hr}\right)$, (b) reverse salt flux $\left(\mathrm{g} / \mathrm{m}^{2} / \mathrm{hr}\right)$, and (c) specific reverse salt flux $(\mathrm{mg} / \mathrm{L})$.

Integrity test results showed that virgin CTA-HS and CTA-LS membrane water flux was approximately 8.7 and $8.5 \mathrm{~L} / \mathrm{m}^{2} / \mathrm{hr}$ and decreased to 7.0 and $5.1 \mathrm{~L} / \mathrm{m}^{2} / \mathrm{hr}$ after 100-days, respectively; virgin TFC-HS and TFC-LS membrane water flux was approximately 11.2 and $11.9 \mathrm{~L} / \mathrm{m}^{2} / \mathrm{hr}$ and decreased to 4.0 and $5.3 \mathrm{~L} / \mathrm{m}^{2} / \mathrm{hr}$ after 100-days, respectively. Water flux through the CTA membranes fouled for 70-days increased to virgin flux levels. The increase was likely because the membrane coupons were retested after storage in deionized water and foulants were dissolved from the membranes. As discussed in the membrane fouling system results, in addition to the fouling layer, CEOP is likely a major contributor to water flux declination for all membranes.

RSF through the CTA and TFC membranes increased over the 100-days, in which CTA membranes outperformed TFC membranes with lower RSF (Fig. 7b) - this trend is therefore reflected in the SRSF results (Fig. 7c). CTA-HS and CTA-LS membranes had much lower SRSF results $(1,350$ and 2,450 mg/L) compared to TFC-HS and TFC-LS membranes $(4,700$ and 7,500 $\mathrm{mg} / \mathrm{L}$ ). The SRSF results for CTA membranes are in agreement with previous studies that used CTA FO membranes to treat activated sludge [2, 84].

The increased SRSF results for both membrane types indicated that reverse salt diffusion increased across the membrane relative to forward water diffusion. Chemical changes in the membrane active layers could have led to the preferential diffusion and FTIR was used to 
explore any chemical changes in the virgin and fouled active layer. FTIR spectra were compared between virgin CTA and TFC membranes and membrane active layers fouled for 100-days in high-salinity and low-salinity feeds. FTIR spectra comparisons are shown in Fig. 8.
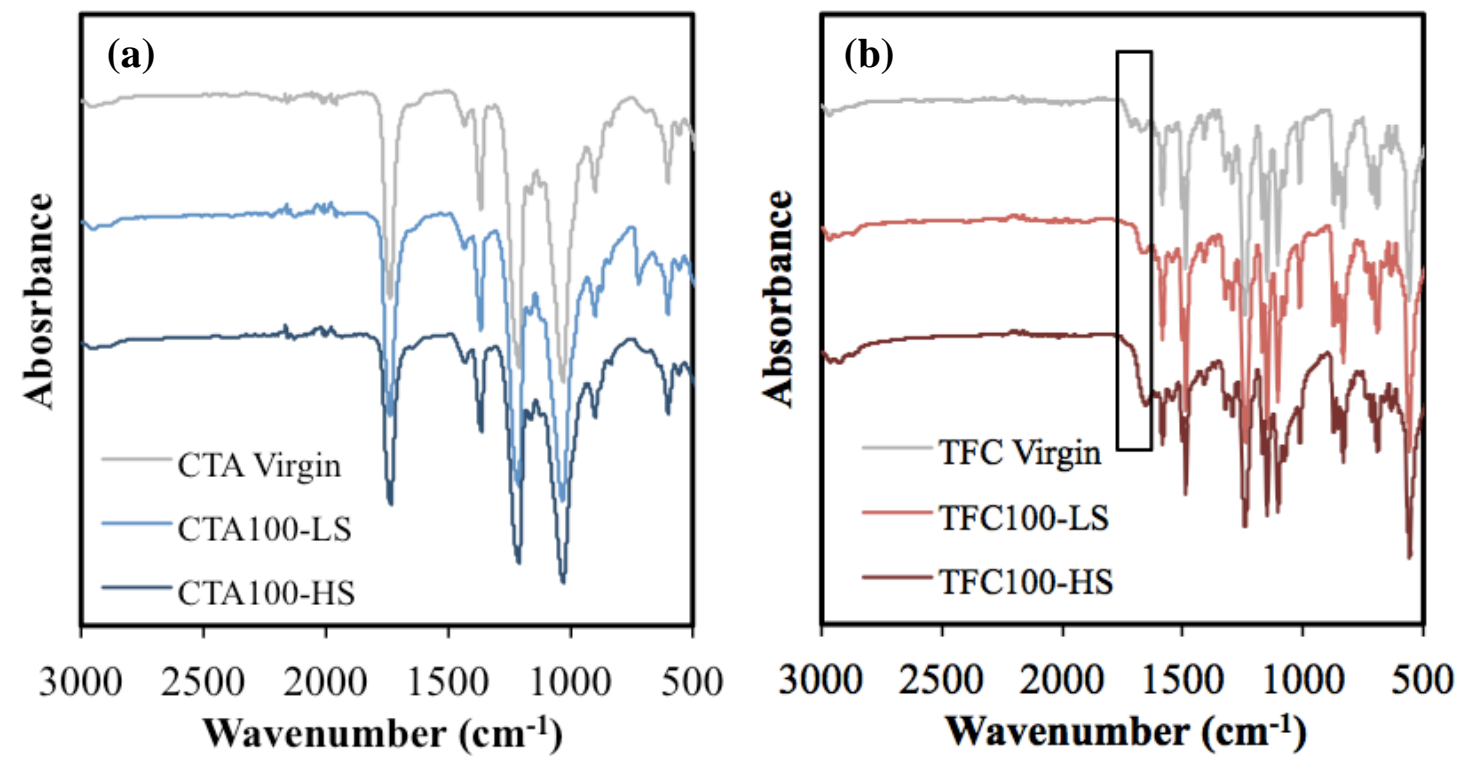

Fig. 8. FTIR spectra for (a) virgin CTA, CTA100-LS, CTA100-HS and (b) virgin TFC, TFC100LS, and CTF100-HS. Box in Fig. 8b highlights peak disappearance at $1711 \mathrm{~cm}^{-1}$ and peak shift at $1671 \mathrm{~cm}^{-1}$ between virgin and fouled TFC membranes.

In general, the membrane chemistry did not change for the CTA and TFC membranes. The TFC membranes had a peak disappearance at $1711 \mathrm{~cm}^{-1}$ and a peak shift at $1671 \mathrm{~cm}^{-1}$ (box in Fig. 8b) but this is likely due to the dissolution of solvent used in the membrane synthesis [85]. Thus, changes in SRSF are not likely caused by chemical changes in the membrane active layers.

ESEM was used to determine if physical defects were present on membrane active layer; it is possible that defects compromised the selectivity of the membrane, as proposed in a previous study [2]. CTA and TFC membrane active layers were analyzed with ESEM to determine if any defects developed over the experimental period. An ESEM micrograph of a membrane defect found on a TFC-LS membrane fouled for 100-days is shown in Fig. 9. 


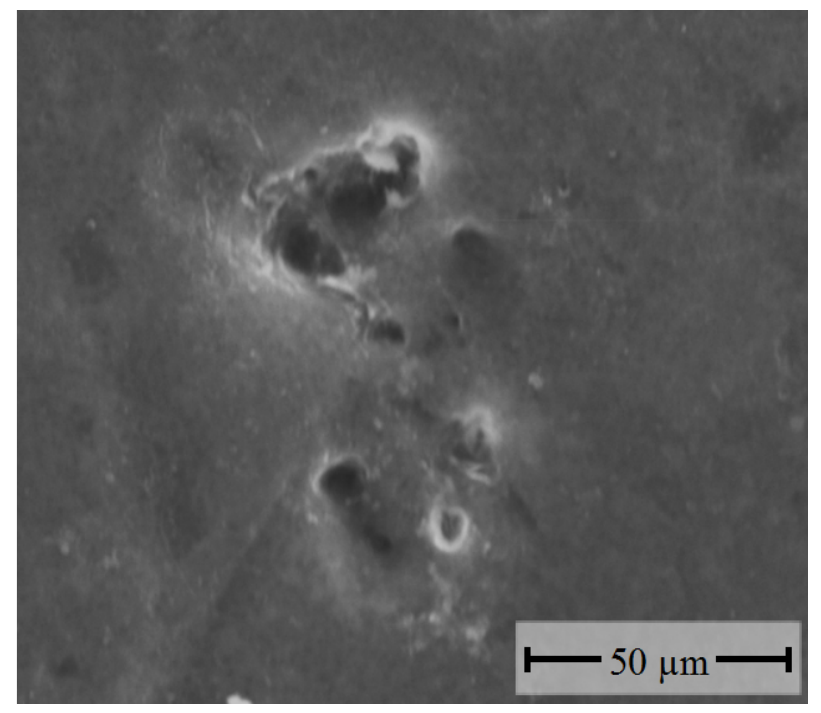

Fig. 9. An ESEM micrograph (2500x) of the TFC-LS membrane that was fouled for 100 days.

The ESEM micrograph in Fig. 9 is representative of physical defects that were found for TFC-LS membranes fouled for 40, 70, and 100 days. Multiple defects were found on randomly sampled membrane coupons, and these defects most likely caused the dramatic SRSF increases for TFC-LS membranes that were as high as $17,675 \mathrm{mg} / \mathrm{L}$. Defects were not found on the CTAHS, CTA-LS, or TFC-HS membrane active layers and therefore, were not likely the cause of increased SRSF for all membranes.

Fouling layers may offer another explanation for the increased SRSF. Two studies have proposed that increased SRSF occurs because of charge imbalances caused by negatively charged fouling layers [2, 86]. Kim et al. [86] and Hancock et al. [2] both proposed that SRSF increased because of a higher reverse flux of cations (e.g., sodium) that were attracted to the negatively charged fouling layer. Indeed, Lu et al. [87] demonstrated that more negatively charged membrane surfaces caused increased sodium flux. The study also found that changes in chemical potential between the feed and DS highly affected cation diffusion in TFC membranes, but did not affect sodium diffusion in CTA membranes. The authors attributed higher cation diffusion in the TFC membranes to negatively charged fixed surface sites (i.e., carboxyl groups) and lower cation diffusion in CTA membranes to non-fixed surface charges. Negatively charged fouling layers were shown by Hancock et al. [2] for CTA membranes that treated activated sludge for 54 days. The membranes in the present study may have also obtained increasingly 
negative fouling layers, resulting in increased SRSF, and the TFC membranes may have been more affected by the fouling layer charge imbalance than the CTA membranes. The effect of fouling on SRSF remains unclear, and future work is needed to further the understanding of this relationship.

\section{Conclusion}

The performance and fouling mechanisms of commercially available CTA and TFC membranes were evaluated during 100-days of continuous activated sludge treatment. Two MBRs provided activated sludge with high salinity and low MLSS concentrations or low-salinity and high MLSS concentrations. Overall, CTA membranes outperformed TFC membranes, exhibiting higher steady-state water flux and lower SRSF over the 100-day testing period. Increased SRSF for both membranes tested were likely caused by the organic fouling layer covering the membrane surface. The effects of fouling on SRSF remain unclear and systematic studies are needed to further the understanding of this relationship.

Water flux for the CTA and TFC membranes were comparable between feed compositions and illustrated that TDS, calcium, and MLSS concentrations might have negligible effects on FO fouling propensity in OMBR applications. TFC membranes were more prone to fouling and it was demonstrated that hydrophilicity and surface roughness were not the primary contributors to membrane fouling propensity. ESEM and FTIR results showed a predominance of biofouling and organic fouling, and fouling layer compositions did not differ between membrane and feed types. Overall, the study demonstrated that FO membranes are suitable for long-term OMBR operation and reliably perform under a variety of activated sludge conditions.

\section{Acknowledgments}

The authors would like to thank the National Science Foundation Engineering Research Center Program under Cooperative Agreement EEC- 1028968 (ReNUWIt) for supporting this study. Additional financial support for this work was provided by ConocoPhillips through their contribution to the Center for a Sustainable $\mathrm{WE}^{2} \mathrm{ST}$ (Water-Energy Education, Science, and Technology) at Colorado School of Mines. This Center was established to promote the joint sustainability of unconventional energy development and water resources in arid regions. 
Findings, opinions, and conclusions in this work are those of the author and are not a statement or representation of the views, policies or opinions of ConocoPhillips or its employees or representatives. The authors would like to thank Hydration Technology Innovations for providing membranes for the study and to Aqua-Aerobic Systems, Inc., for their long-term support of research at the Colorado School of Mines. The authors would also like to thank Estefani Bustos and Mike Veres for their assistance with laboratory analyses and technical support.

\section{List of Abbreviations}

$\begin{array}{ll}\text { AFM } & \text { Atomic force microscopy } \\ \text { CA } & \text { Cellulose acetate } \\ \text { CECP } & \text { Cake enhanced concentration polarization } \\ \text { COD } & \text { Chemical oxygen demand } \\ \text { CTA } & \text { Cellulose triacetate } \\ \text { DOC } & \text { Dissolved organic carbon } \\ \text { DS } & \text { Draw solution } \\ \text { EDS } & \text { Energy dispersive spectroscopy } \\ \text { EPS } & \text { Extracellular polymeric substances } \\ \text { ESEM } & \text { Environmental scanning electron microscope } \\ \text { FO } & \text { Forward osmosis } \\ \text { FTIR } & \text { Fourier transform infrared spectroscopy } \\ \text { HRT } & \text { Hydraulic retention time } \\ \text { HS } & \text { High-salinity } \\ \text { HTI } & \text { Hydration technology innovations, LLC } \\ \text { IC } & \text { Ion chromatograph } \\ \text { ICP-AES } & \text { Inductively coupled plasma atomic emission spectroscopy } \\ \text { LS } & \text { Low-salinity } \\ \text { MBR } & \text { Membrane bioreactor } \\ \text { MF } & \text { Microfiltration } \\ \text { MLSS } & \text { Mixed liquor suspended solids } \\ \text { MLVSS } & \text { Mixed liquor volatile suspended solids } \\ \text { NF } & \text { Nanofiltration } \\ \text { OMBR } & \text { Osmotic membrane bioreactor } \\ \text { PA } & \text { Polyamide } \\ \text { RO } & \text { Reverse osmosis } \\ \text { RSF } & \text { Reverse salt flux } \\ \text { SB-MBR } & \text { Sequencing batch membrane bioreactor } \\ \text { SBR } & \text { Sequencing batch reactors } \\ \text { SMP } & \text { Soluble microbial products } \\ \text { SPE } & \text { Solid-phase extraction } \\ \text { SRSF } & \text { Specific reverse salt flux } \\ \text { SRT } & \text { Solids retention time } \\ & \end{array}$




$\begin{array}{ll}\text { TDS } & \text { Total dissolved solids } \\ \text { TFC } & \text { Thin film composite } \\ \text { TOC } & \text { Total organic carbon } \\ \text { TN } & \text { Total nitrogen } \\ \text { TP } & \text { Total phosphorus } \\ \text { TSS } & \text { Total dissolved solids } \\ \text { UF } & \text { Ultrafiltration } \\ \text { UFO-MBR } & \text { Ultrafiltration-osmotic membrane bioreactor }\end{array}$

\section{References}

[1] R.W. Holloway, A.S. Wait, A. Fernandes da Silva, J. Herron, M.D. Schutter, K. Lampi, T.Y. Cath, Long-term pilot scale investigation of novel hybrid ultrafiltration-osmotic membrane bioreactors, Desalination 363 (2015) 64-74.

[2] N.T. Hancock, P. Xu, M.J. Roby, J.D. Gomez, T.Y. Cath, Towards direct potable reuse with forward osmosis: Technical assessment of long-term process performance at the pilot scale, Journal of Membrane Science 445 (2013) 34-46.

[3] A. Achilli, T.Y. Cath, E.A. Marchand, A.E. Childress, The forward osmosis membrane bioreactor: A low fouling alternative to MBR processes, Desalination 239 (2009) 10-21.

[4] T.Y. Cath, A.E. Childress, M. Elimelech, Forward osmosis: Principles, applications, and recent developments, Journal of Membrane Science 281 (2006) 70-87.

[5] R.W. Holloway, A. Achilli, T.Y. Cath, The osmotic membrane bioreactor: a critical review, Environmental Science: Water Research \& Technology 1 (2015) 581-605.

[6] L.A. Hoover, W.A. Phillip, A. Tiraferri, N.Y. Yip, M. Elimelech, Forward with osmosis: Emerging applications for greater sustainability, Environmental Science \& Technology 45 (2011) 9824-9830.

[7] M. Xie, W.E. Price, L.D. Nghiem, Rejection of pharmaceutically active compounds by forward osmosis: Role of solution $\mathrm{pH}$ and membrane orientation, Separation and Purification Technology 93 (2012) 107-114.

[8] J.L. Cartinella, T.Y. Cath, M.T. Flynn, G.C. Miller, K.W. Hunter, A.E. Childress, Removal of natural steroid hormones from wastewater using membrane contactor processes, Environmental Science \& Technology 40 (2006) 7381-7386.

[9] T.Y. Cath, N.T. Hancock, C.D. Lundin, C. Hoppe-Jones, J.E. Drewes, A multi-barrier osmotic dilution process for simultaneous desalination and purification of impaired water, Journal of Membrane Science 362 (2010) 417-426. 
[10] R. Valladares Linares, V. Yangali-Quintanilla, Z. Li, G. Amy, Rejection of micropollutants by clean and fouled forward osmosis membrane, Water Research 45 (2011) 6737-6744.

[11] N.T. Hancock, P. Xu, D.M. Heil, C. Bellona, T.Y. Cath, Comprehensive bench- and pilot-scale investigation of trace organic compounds rejection by forward osmosis, Environmental Science \& Technology 45 (2011) 8483-8490.

[12] M. Xie, L.D. Nghiem, W.E. Price, M. Elimelech, Comparison of the removal of hydrophobic trace organic contaminants by forward osmosis and reverse osmosis, Water Research 46 (2012) 2683-2692.

[13] R.W. Holloway, J. Regnery, L.D. Nghiem, T.Y. Cath, Removal of trace organic chemicals and performance of a novel hybrid ultrafiltration-osmotic membrane bioreactor, Environmental Science \& Technology 48 (2014) 10859-10868.

[14] B.D. Coday, B.G. Yaffe, P. Xu, T.Y. Cath, Rejection of trace organic compounds by forward osmosis membranes: a literature review, Environmental Science \& Technology 48 (2014) 3612-3624.

[15] K.L. Hickenbottom, N.T. Hancock, N.R. Hutchings, E.W. Appleton, E.G. Beaudry, P. $\mathrm{Xu}, \mathrm{T} . \mathrm{Y}$. Cath, Forward osmosis treatment of drilling mud and fracturing wastewater from oil and gas operations, Desalination 312 (2013) 60-66.

[16] B.D. Coday, D.M. Heil, P. Xu, T.Y. Cath, Effects of transmembrane hydraulic pressure on performance of forward osmosis membranes, Environmental Science \& Technology 47 (2013) 2386-2393.

[17] H. Yamamura, K. Kimura, Y. Watanabe, Mechanism involved in the evolution of physically irreversible fouling in microfiltration and ultrafiltration membranes used for drinking water treatment, Environmental Science \& Technology 41 (2007) 6789-6794.

[18] A. Drews, Membrane fouling in membrane bioreactors-characterisation, contradictions, cause and cures, Journal of Membrane Science 363 (2010) 1-28.

[19] S. Judd, The MBR book: principles and applications of membrane bioreactors for water and wastewater treatment, Elsevier, 2010, 0080967671.

[20] B. Mi, M. Elimelech, Organic fouling of forward osmosis membranes: Fouling reversibility and cleaning without chemical reagents, Journal of Membrane Science 348 (2010) 337-345.

[21] R.W. Holloway, A.E. Childress, K.E. Dennett, T.Y. Cath, Forward osmosis for concentration of anaerobic digester centrate, Water Research 41 (2007) 4005-4014. 
[22] S. Lee, C. Boo, M. Elimelech, S. Hong, Comparison of fouling behavior in forward osmosis (FO) and reverse osmosis (RO), Journal of Membrane Science 365 (2010) 34-39.

[23] F. Meng, S.-R. Chae, A. Drews, M. Kraume, H.-S. Shin, F. Yang, Recent advances in membrane bioreactors (MBRs): Membrane fouling and membrane material, Water Research 43 (2009) 1489-1512.

[24] M.T. Madigan, J.M. Martinko, K.S. Bender, D.H. Buckley, D.A. Stahl, Brock biology of microorganisms, 14th Edition, Benjamin Cummings, 2014, 9780321897398

[25] T. Nguyen, F. Roddick, L. Fan, Biofouling of water treatment membranes: A review of the underlying causes, monitoring techniques and control measures, Membranes 2 (2012) 804-840.

[26] I.-J. Kang, S.-H. Yoon, C.-H. Lee, Comparison of the filtration characteristics of organic and inorganic membranes in a membrane-coupled anaerobic bioreactor, Water Research 36 (2002) 1803-1813.

[27] S. Ognier, C. Wisniewski, A. Grasmick, Characterisation and modelling of fouling in membrane bioreactors, Desalination 146 (2002) 141-147.

[28] W.C. Lay, Q. Zhang, J. Zhang, D. McDougald, C. Tang, R. Wang, Y. Liu, A.G. Fane, Study of integration of forward osmosis and biological process: Membrane performance under elevated salt environment, Desalination 283 (2011) 123-130.

[29] M.M. Motsa, B.B. Mamba, A. D’Haese, E.M. Hoek, A.R. Verliefde, Organic fouling in forward osmosis membranes: The role of feed solution chemistry and membrane structural properties, Journal of Membrane Science 460 (2014) 99-109.

[30] A. Tiraferri, Improving the performance and antifouling properties of thin-film composite membranes for water separation technologies, Yale University, 2012, 1267856769.

[31] K. Boussu, A. Belpaire, A. Volodin, C. Van Haesendonck, P. Van Der Meeren, C. Vandecasteele, B. Van der Bruggen, Influence of membrane and colloid characteristics on fouling of nanofiltration membranes, Journal of Membrane Science 289 (2007) 220230.

[32] H. Susanto, M. Ulbricht, Photografted thin polymer hydrogel layers on PES ultrafiltration membranes: characterization, stability, and influence on separation performance, Langmuir 23 (2007) 7818-7830.

[33] Y.-N. Wang, C.Y. Tang, Protein fouling of nanofiltration, reverse osmosis, and ultrafiltration membranes - the role of hydrodynamic conditions, solution chemistry, and membrane properties, Journal of Membrane Science 376 (2011) 275-282. 
[34] N. Maximous, G. Nakhla, W. Wan, Comparative assessment of hydrophobic and hydrophilic membrane fouling in wastewater applications, Journal of Membrane Science 339 (2009) 93-99.

[35] Y. He, P. Xu, C. Li, B. Zhang, High-concentration food wastewater treatment by an anaerobic membrane bioreactor, Water Research 39 (2005) 4110-4118.

[36] Y. Gu, Y.-N. Wang, J. Wei, C.Y. Tang, Organic fouling of thin-film composite polyamide and cellulose triacetate forward osmosis membranes by oppositely charged macromolecules, Water Research 47 (2013) 1867-1874.

[37] B. Mi, M. Elimelech, Chemical and physical aspects of organic fouling of forward osmosis membranes, Journal of Membrane Science 320 (2008) 292-302.

[38] W. Lay, T. Chong, C. Tang, A. Fane, J. Zhang, Y. Liu, Fouling propensity of forward osmosis: Investigation of the slower flux decline phenomenon, Water Science \& Technology 61 (2010) 927-936.

[39] M. Elimelech, X. Zhu, A.E. Childress, S. Hong, Role of membrane surface morphology in colloidal fouling of cellulose acetate and composite aromatic polyamide reverse osmosis membranes, Journal of Membrane Science 127 (1997) 101-109.

[40] J.-M. Tan, G. Qiu, Y.-P. Ting, Osmotic membrane bioreactor for municipal wastewater treatment and the effects of silver nanoparticles on system performance, Journal of Cleaner Production 88 (2015) 146-151.

[41] L. Ye, C.-y. Peng, B. Tang, S.-y. Wang, K.-f. Zhao, Y.-z. Peng, Determination effect of influent salinity and inhibition time on partial nitrification in a sequencing batch reactor treating saline sewage, Desalination 246 (2009) 556-566.

[42] X. Wang, Y. Chen, B. Yuan, X. Li, Y. Ren, Impacts of sludge retention time on sludge characteristics and membrane fouling in a submerged osmotic membrane bioreactor, Bioresource Technology 161 (2014) 340-347.

[43] V. Parida, H.Y. Ng, Forward osmosis organic fouling: Effects of organic loading, calcium and membrane orientation, Desalination 312 (2013) 88-98.

[44] S.S. Ghayeni, P. Beatson, R. Schneider, A. Fane, Adhesion of waste water bacteria to reverse osmosis membranes, Journal of Membrane Science 138 (1998) 29-42.

[45] S.B. Sadr Ghayeni, P.J. Beatson, R.P. Schneider, A.G. Fane, Adhesion of waste water bacteria to reverse osmosis membranes, Journal of Membrane Science 138 (1998) 29-42.

[46] B.D. Coday, T. Luxbacher, A.E. Childress, N. Almaraz, P. Xu, T.Y. Cath, Indirect determination of zeta potential at High Ionic strength: specific application to semipermeable polymeric membranes, Journal of Membrane Science 478 (2015) 58-64. 
[47] P. Xu, J.E. Drewes, T.-U. Kim, C. Bellona, G. Amy, Effect of membrane fouling on transport of organic contaminants in NF/RO membrane applications, Journal of Membrane Science 279 (2006) 165-175.

[48] M.R. Wiesner, S. Chellam, Peer reviewed: the promise of membrane technology, Environmental Science \& Technology 33 (1999) 360A-366A.

[49] C.Y. Tang, Q. She, W.C.L. Lay, R. Wang, A.G. Fane, Coupled effects of internal concentration polarization and fouling on flux behavior of forward osmosis membranes during humic acid filtration, Journal of Membrane Science 354 (2010) 123-133.

[50] J. Zhang, W.L.C. Loong, S. Chou, C. Tang, R. Wang, A.G. Fane, Membrane biofouling and scaling in forward osmosis membrane bioreactor, Journal of Membrane Science 403404 (2012) 8-14.

[51] Q. Zhang, Y.W. Jie, W.L.C. Loong, J. Zhang, A.G. Fane, S. Kjelleberg, S.A. Rice, D. McDougald, Characterization of biofouling in a lab-scale forward osmosis membrane bioreactor (FOMBR), Water Research 58 (2014) 141-151.

[52] C. Boo, M. Elimelech, S. Hong, Fouling control in a forward osmosis process integrating seawater desalination and wastewater reclamation, Journal of Membrane Science 444 (2013) 148-156.

[53] C. Boo, S. Lee, M. Elimelech, Z. Meng, S. Hong, Colloidal fouling in forward osmosis: role of reverse salt diffusion, Journal of Membrane Science 390 (2012) 277-284.

[54] Y. Liu, B. Mi, Combined fouling of forward osmosis membranes: synergistic foulant interaction and direct observation of fouling layer formation, Journal of Membrane Science 407 (2012) 136-144.

[55] X. Lu, L.H. Arias Chavez, S. Romero-Vargas Castrillón, J. Ma, M. Elimelech, Influence of active layer and support layer surface structures on organic fouling propensity of thinfilm composite forward osmosis membranes, Environmental Science \& Technology 49 (2015) 1436-1444.

[56] Y. Wang, F. Wicaksana, C.Y. Tang, A.G. Fane, Direct microscopic observation of forward osmosis membrane fouling, Environmental Science \& Technology 44 (2010) 7102-7109.

[57] S. Zou, Y.-N. Wang, F. Wicaksana, T. Aung, P.C.Y. Wong, A.G. Fane, C.Y. Tang, Direct microscopic observation of forward osmosis membrane fouling by microalgae: critical flux and the role of operational conditions, Journal of Membrane Science 436 (2013) 174-185. 
[58] R. Valladares Linares, Z. Li, M. Abu-Ghdaib, C.-H. Wei, G. Amy, J.S. Vrouwenvelder, Water harvesting from municipal wastewater via osmotic gradient: An evaluation of process performance, Journal of Membrane Science 447 (2013) 50-56.

[59] R. Valladares Linares, V. Yangali-Quintanilla, Z. Li, G. Amy, NOM and TEP fouling of a forward osmosis (FO) membrane: Foulant identification and cleaning, Journal of Membrane Science 421-422 (2012) 217-224.

[60] H. Zhang, Y. Ma, T. Jiang, G. Zhang, F. Yang, Influence of activated sludge properties on flux behavior in osmosis membrane bioreactor (OMBR), Journal of Membrane Science 390 (2012) 270-276.

[61] M. Villain, I. Bourven, G. Guibaud, B. Marrot, Impact of synthetic or real urban wastewater on membrane bioreactor (MBR) performances and membrane fouling under stable conditions, Bioresource Technology 155 (2014) 235-244.

[62] B.D. Coday, N. Almaraz, T.Y. Cath, Forward osmosis desalination of oil and gas wastewater: Impacts of membrane selection and operating conditions on process performance, Journal of Membrane Science 488 (2015) 40-55.

[63] D. Vuono, J. Henkel, J. Benecke, T.Y. Cath, T. Reid, L. Johnson, J.E. Drewes, Flexible hybrid membrane treatment systems for tailored nutrient management: A new paradigm in urban wastewater treatment, Journal of Membrane Science 446 (2013) 34-41.

[64] N.T. Hancock, T.Y. Cath, Solute coupled diffusion in osmotically driven membrane processes, Environmental Science \& Technology 43 (2009) 6769-6775.

[65] W.A. Phillip, J.S. Yong, M. Elimelech, Reverse draw solute permeation in forward osmosis: Modeling and experiments, Environmental Science \& Technology 44 (2010) 5170-5176.

[66] N.T. Hancock, Engineered osmosis: Assessment of mass transport and sustainable hybrid system configurations for desalination and water reclamation, The Colorado School of Mines, Golden, CO (2011).

[67] T.Y. Cath, M. Elimelech, J.R. McCutcheon, R.L. McGinnis, A. Achilli, D. Anastasio, A.R. Brady, A.E. Childress, I.V. Farr, N.T. Hancock, J. Lampi, L.D. Nghiem, M. Xie, N.Y. Yip, Standard methodology for evaluating membrane performance in osmotically driven membrane processes, Desalination 312 (2013) 31-38.

[68] E.M. Hoek, M. Elimelech, Cake-enhanced concentration polarization: a new fouling mechanism for salt-rejecting membranes, Environmental Science \& Technology 37 (2003) 5581-5588. 
[69] J.R. McCutcheon, M. Elimelech, Influence of concentrative and dilutive internal concentration polarization on flux behavior in forward osmosis, Journal of Membrane Science 284 (2006) 237-247.

[70] C.H. Tan, H.Y. Ng, Modified models to predict flux behavior in forward osmosis in consideration of external and internal concentration polarizations, Journal of Membrane Science 324 (2008) 209-219.

[71] M. Xie, L.D. Nghiem, W.E. Price, M. Elimelech, Impact of organic and colloidal fouling on trace organic contaminant rejection by forward osmosis: Role of initial permeate flux, Desalination 336 (2014) 146-152.

[72] C. Jarusutthirak, G. Amy, Role of soluble microbial products (SMP) in membrane fouling and flux decline, Environmental Science \& Technology 40 (2006) 969-974.

[73] K.M. Kemner, S.D. Kelly, B. Lai, J. Maser, E.J. O'Loughlin, D. Sholto-Douglas, Z. Cai, M.A. Schneegurt, C.F. Kulpa, K.H. Nealson, Elemental and redox analysis of single bacterial cells by X-ray microbeam analysis, Science 306 (2004) 686-687.

[74] S. Lee, W.S. Ang, M. Elimelech, Fouling of reverse osmosis membranes by hydrophilic organic matter: implications for water reuse, Desalination 187 (2006) 313-321.

[75] P. van den Brink, A. Zwijnenburg, G. Smith, H. Temmink, M. van Loosdrecht, Effect of free calcium concentration and ionic strength on alginate fouling in cross-flow membrane filtration, Journal of Membrane Science 345 (2009) 207-216.

[76] A.J. de Kerchove, M. Elimelech, Structural growth and viscoelastic properties of adsorbed alginate layers in monovalent and divalent salts, Macromolecules 39 (2006) 6558-6564.

[77] W. Luo, F.I. Hai, W.E. Price, L.D. Nghiem, Water extraction from mixed liquor of an aerobic bioreactor by forward osmosis: Membrane fouling and biomass characteristics assessment, Separation and Purification Technology 145 (2015) 56-62.

[78] G. Qiu, Y.-P. Ting, Short-term fouling propensity and flux behavior in an osmotic membrane bioreactor for wastewater treatment, Desalination 332 (2014) 91-99.

[79] J.A. Brant, A.E. Childress, Assessing short-range membrane-colloid interactions using surface energetics, Journal of Membrane Science 203 (2002) 257-273.

[80] P. Campbell, R. Srinivasan, T. Knoell, D. Phipps, K. Ishida, J. Safarik, T. Cormack, H. Ridgway, Quantitative structure-activity relationship (QSAR) analysis of surfactants influencing attachment of a Mycobacterium sp. to cellulose acetate and aromatic polyamide reverse osmosis membranes, Biotechnology and Bioengineering 64 (1999) 527-544. 
[81] H. Ma, C.J. Winslow, B.E. Logan, Spectral force analysis using atomic force microscopy reveals the importance of surface heterogeneity in bacterial and colloid adhesion to engineered surfaces, Colloids and Surfaces B: Biointerfaces 62 (2008) 232-237.

[82] M. Elimelech, Z. Xiaohua, A.E. Childress, H. Seungkwan, Role of membrane surface morphology in colloidal fouling of cellulose acetate and composite aromatic polyamide reverse osmosis membranes, Journal of Membrane Science 127 (1997) 101-109.

[83] B. Mi, M. Elimelech, Silica scaling and scaling reversibility in forward osmosis, Desalination 312 (2013) 75-81.

[84] E.R. Cornelissen, D. Harmsen, K.F. de Korte, C.J. Ruiken, J.-J. Qin, H. Oo, L.P. Wessels, Membrane fouling and process performance of forward osmosis membranes on activated sludge, Journal of Membrane Science 319 (2008) 158-168.

[85] S. Belfer, Y. Purinson, O. Kedem, Surface modification of commercial polyamide reverse osmosis membranes by radical grafting: An ATR-FTIR study, Acta Polymerica 49 (1998) 574-582.

[86] C.-M. Kim, S.-J. Kim, L.H. Kim, M.S. Shin, H.-W. Yu, I.S. Kim, Effects of phosphate limitation in feed water on biofouling in forward osmosis (FO) process, Desalination 349 (2014) 51-59.

[87] X. Lu, C. Boo, J. Ma, M. Elimelech, Bidirectional diffusion of ammonium and sodium cations in forward osmosis: Role of membrane active layer surface chemistry and charge, Environmental Science \& Technology 48 (2014) 14369-14376. 